\title{
Na periferia do lugar
}

\author{
Marcelo Oliveira*
}

O que leva um artista a tratar de um ou outro tema específico? Em que medida a sua vivência e escolhas influenciam na obra?

Nasci na Baixada Fluminense do estado do Rio de Janeiro, mais precisamente, Pilar - Duque de Caxias. Tive uma infância livre e sem muitos adultos por perto. Pescava, jogava bola de gude, rodava pião, pique polícialadrão, comia fruta em cima da árvore - essas coisas bem próprias de criança pobre de subúrbio. Aprendi a ler aos nove, quase dez, ia à Escola quando queria e quase nunca queria, preferia pescar ou brincar com os brinquedos que fabricava a estudar.

A mãe, só aos finais de semana, trabalhava em "casa de família" em Laranjeiras. Meu pai sempre desempregado e muito próximo da bebida vivia nas barracas, tomando sua cachaça e jogando sinuca e baralho, o que fazia muito bem. Mas os dois com imenso amor e carinho, duas vítimas sociais. Aos oito ou sete anos, ia ao centro de Caxias junto com outros mais velhos e mais novos ver o mundo. Hoje, concluo que era como esses meninos que perambulam pelas ruas do centro em bandos, descalços, praticando pequenos furtos. Minha especialidade eram livros infantis. E nos perguntamos: Onde andam os pais dessas crianças? Não havia noção de certo e errado, não havia uma educação formal, da maneira que conheço hoje de escola e família. Os caminhos da vida me levaram até a educação, poderia ter levado a outros. Tive sorte.

Os enredos das obras que construo são traçados a partir da observação e registro de algo que desperta para o olhar, dos meios de comunicação visuais legitimados ou dos cartazes populares que anunciam produtos e serviços. Das frases e diálogos que me causam algum incômodo. O contexto da visualidade urbana local, sendo considerado o que estiver dentro e fora da norma culta, as relações de (des)afeto e as reflexões políticas são a massa que dá forma e liga à obra final. Estes são os nortes da pesquisa que desenvolvo. Relato, em seguida, umas das experiências que bem exemplificam o meu processo criativo.

Em recente residência artística no Parque Lage, articulei o projeto "na periferia do lugar". A primeira parte do cronograma, uma semana, previa pesquisa relacional pelo bairro do Jardim Botânico, que começava

\footnotetext{
* Artista plástico e funcionário técnico-administrativo da Universidade do Estado do Rio de Janeiro (UERJ). Email: $<$ marcelomoti@yahoo.com.br>
} 


\section{ReVistg all pautg}

[ NA PERIFERIA DO LUGAR - OLIVEIRA, M. \}

DOI: $10.12957 /$ REP.2016.25437

a partir do parque às 7 h e terminava à noite. Cada dia tomava café da manhã e almoçava em um lugar diferente. Conversas com um, com outro. Fotografias, desenho aqui e ali. Muita observação das pessoas, arquitetura, lojas, cartazes e letreiros. Passava um tempo olhando as revistas de fofoca e jornais pendurados nas bancas da região, material farto de pesquisa. Um deles com o seguinte título: REVELAÇÂO - Anitta declara: - Perdi a virgindade aos 18. Acima, uma foto da artista, que por alguns segundos pensei ser o Michael Jackson. Sai imaginando a quem interessaria esta revelação.

Lá pelo quarto dia, comentei comigo mesmo: - só tem gente bonita nesse lugar, tudo lindo, prédios, casas, vários condomínios com nome de condes, barões, natureza exuberante!!. - Não tem nenhuma comunidade?

Na Pacheco Leão, ao lado do Jardim Botânico e da rede globo, pergunto a um senhor que trabalhava no ponto de táxi: TEM ALGUMA COMUNIDADE POR AQUI? Ele me responde em tom ríspido, - FAVELA? AQUI NÃO TEM FAVELA! SÓ CONDOMÍNIO RESIDENCIAL. Agradeci e me afastei. Deduzi, depois, que morava na região e não queria ser chamado de favelado, ou que agiu assim por imaginar que estava a procura de drogas. Tudo especulação.

Segui e verifiquei que há pelo menos três comunidades nesta rua, a do Caxinquelê, do Balança e uma outra que vai margeando um pequeno rio. Constatei, também, uma certa tensão na região, muitas faixas em português e inglês denunciando uma possível ação da prefeitura para retirá-los de lá. Coisas do tipo: NASCI AQUI, CRIEI MEUS FILHOS E NETOS Ou O HORTO É DE QUEM NASCEU NELE - MORO AQUI HÁ DÉCADAS! De fato, em conversa com uma senhora de 85 anos, que saiu de uma das casas, relatou que seu pai trabalhava no Jardim Botânico, que casou, criou seus filhos, seu marido morreu ali e agora vê seus netos crescerem e acha difícil tirarem ela de lá, que essa história é muito antiga.

Meu projeto previa a realização de uma obra, criada a partir dessa vivência, que seria devolvida em forma de intervenção urbana, buscando reproduzir o estímulo captado, além de participar de uma exposição, fechando a residência. Muitas coisas me tocaram, mas a frase "FAVELA AQUI NÃO TEM FAVELA" ficou martelando na mente. Falar de favela no Parque Lage, local onde a elite carioca das artes visuais se encontra, cursos caríssimos, uma instituição pública gerenciada por uma Organização Social (OS), fiquei temeroso, mas confiei na minha verdade e na função de uma instituição de ensino e reflexão da arte contemporânea, trabalhei exatamente sobre a frase.

Pensei numa imagem que pudesse se destacar no contexto visual de uma comunidade, quase sempre recheada de informações, e que as pessoas pudessem intervir, caso desejassem. Uma grande massa da cor preta, com um relevo, como uma parede chapiscada, remetendo ao tipo de cobertura tanto usada nessas áreas, a frase, e algumas faixas vermelhas para 


\section{ReVistg all paUtg}

\} NA PERIFERIA DO LUGAR - OLIVEIRA, M. \}

DOI: $10.12957 /$ REP.2016.25437

criarem a atração. Optei não pontuar a frase para deixar a sentença em aberto, sem conduzir a leitura do interlocutor. Fiz várias cópias a partir da matriz criada, essa foi a segunda etapa.

A última consistiu na intervenção com o trabalho nas comunidades próximas e na redondeza do parque. Uma das fases mais ricas. Relatarei apenas três situações:

Antes de intervir num muro próximo ao Horto, vi um portão aberto que levava a um grupo de pequenas casas num nível mais abaixo, que tinham as portas umas de frente para as outras. Resolvi pedir permissão. Desci, verifiquei algumas mulheres e crianças. Uma mulher negra, muito bonita, com os cabelos cheios de tranças me olhou com a pergunta estampada: o quê você quer aqui? Expliquei imediatamente do que se tratava, ela sem pensar muito autorizou e disse que se alguém falasse algo, bastava dizer que a Regina tinha deixado. Assim o fiz, quando estava fazendo a intervenção um homem robusto de aparência e sotaque nordestino perguntou quem me tinha autorizado. Respondi que a Regina, no mesmo instante ele diz: - Ah!! Sim, sim, tudo bem, é a minha mulher. Achei engraçado, sua feição dura desmontou rapidamente, quando disse o nome Regina. Não por acaso essa reação, um exemplo, para mim de como as mulheres tem um papel de liderança e força em comunidades. Inclusive, em muitos casos, é a única fonte de renda ou que, além de complementá-la, ainda faz duas jornadas de trabalho - os afazeres do lar e uma ocupação remuneratória. Tantas mães cumpriram e cumprem este papel, como a minha, reconheci de imediato esse traço tão próximo e peculiar.

A outra foi na comunidade do Balança, que são os moradores oriundos da remoção da antiga favela Praia do Pinto do entorno da Lagoa, na década de 60, por Carlos Lacerda. Para ter acesso ao conjunto de pequenos prédios, tive que me identificar no portão por interfone. Para minha surpresa, a liberação de quem entrava era feita de dentro de um típico "butiquim"/armazém, lugar perfeito para fazer uma intervenção. Conversei com a moça do bar sobre a proposta, mostrei o trabalho, ela disse que lá não seria possível, o patrão não gostaria. Indicou-me a síndica para eu intervir em outra área do condomínio. Mas antes que eu fosse, pediu-me para colocar em sua casa, do outro lado da rua, pois estavam querendo removê-la também. Entendi que ela precisava explicitar que não queria ser identificada como favelada, como moradora de comunidade, com todo o tipo de preconceito que vem com o rótulo. E, principalmente, proteger o teto sobre as cabeças da sua família.

E, por fim, fiz algumas intervenções nas proximidades do Parque. Achei bastante curioso que, justamente, da obra que estava em frente ao Parque Lage retiraram somente a palavra favela. Quem fez essa ação talvez estivesse querendo afastar de todo modo essa conjugação. Por outro lado, sabemos que a força de trabalho que atende aos moradores desse distinto bairro vem das áreas mais pobres de todo canto da cidade. Já, nas co- 


\section{ReVistg eml paUtg}

\} NA PERIFERIA DO LUGAR - OLIVEIRA, M. \}

DOI: $10.12957 / R E P .2016 .25437$

munidades, a reação foi outra, não houve nenhum tipo de intervenção. $\mathrm{Na}$ realidade, havia uma acolhida, as pessoas pediam para eu colocar em suas casas. Era como se eles quisessem dizer: "- Nós não somos favelados!" ou "Temos nossa organização - aqui não é bagunça!!" FAVELA, AQUI NÃO TEM FAVELA! De fato, o que eles querem é afastar a possibilidade da remoção e, além disso, precisam ser reconhecidos e respeitados enquanto partes integrantes desse todo, que é a cidade, com todas as suas contradições.

Importante ressaltar que essas últimas frases são suposições minhas sobre a possibilidade dessas pessoas não quererem ser reconhecidas como residentes de comunidade, como se isso fosse demérito. Não terem o entendimento que a constituição dessa teia urbana e social é fruto das relações estabelecidas dentro da própria cidade.

Retomando as perguntas, no início do texto, sobre processos de criação e motivação, não tenho a intenção de respondê-las, mas situar meu fazer artístico. Em geral, sou impulsionado por questões da visualidade urbana associados à reflexão crítica e, até mesmo, uma dose de ironia. A relação que estabeleço com o outro, a apropriação de partes de diálogos ou frases e imagens retiradas de cartazes e anúncios populares me interessam, assim como as questões políticas. Toda essa massa é aglutinada, reprocessada mentalmente e devolvida em linguagem plástica.

A gravura é a técnica escolhida como meio para expressar essas observações, e que por si só já tem um conceito implícito de democratização da arte que muito me interessa. Pois, pressupõe uma matriz de onde são retiradas cópias impressas, assim seu alcance é maior, possibilitando várias intervenções com seus múltiplos e, também, preços menores, já que não resulta em obra única.

As matrizes dos trabalhos são muitas vezes garimpadas de caçambas de lixo ou encontradas por acaso, materiais descartados, que em sua grande maioria já trazem uma memória do uso e do tempo, que inevitavelmente são transferidos para as estampas no processo de impressão.

Trabalho com as questões políticas e sociais do aqui e agora, com as situações que me tocam, na maioria das vezes, pelo viés crítico. Por outro lado, busco atingir o interlocutor através de sentenças um tanto abertas, sem fechar muito as possibilidades de interpretação da obra, para que o outro coloque sua subjetividade nessa relação. 


\section{heVistg all pautg}

\} NA PERIFERIA DO LUGAR - OLIVEIRA, M. \}

DOI: $10.12957 /$ REP.2016.25437

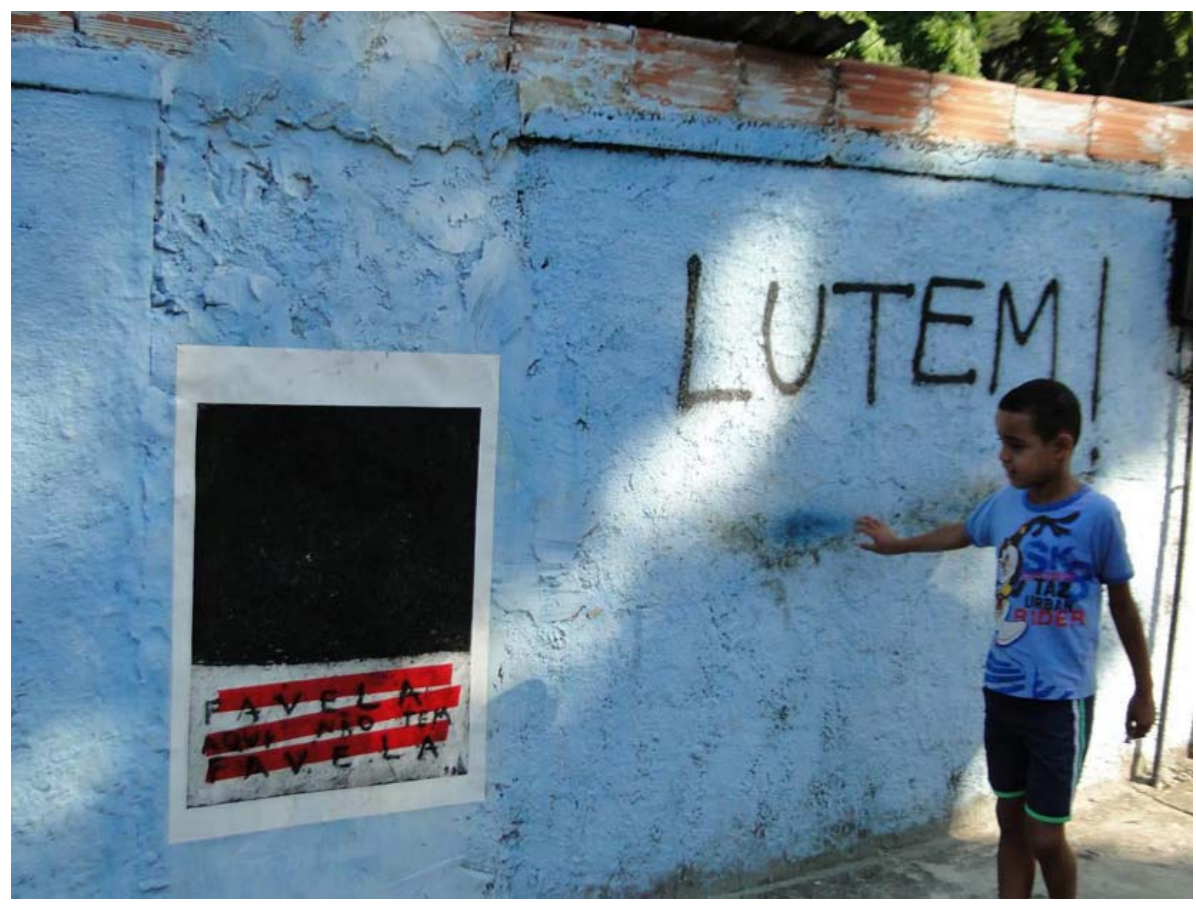

\section{Marcelo Oliveira}

Registro fotográfico das intervenções feitas nas comunidades próximas ao Parque Lage/Rio de Janeiro, a propósito da residência artística do PRÊMIO EAV PARQUE LAGE e MULTIPLO ESPAÇO ARTE 2014 


\section{ReVistg all pautg}

\} NA PERIFERIA DO LUGAR - OLIVEIRA, M. \}

DOI: $10.12957 / R E P .2016 .25437$

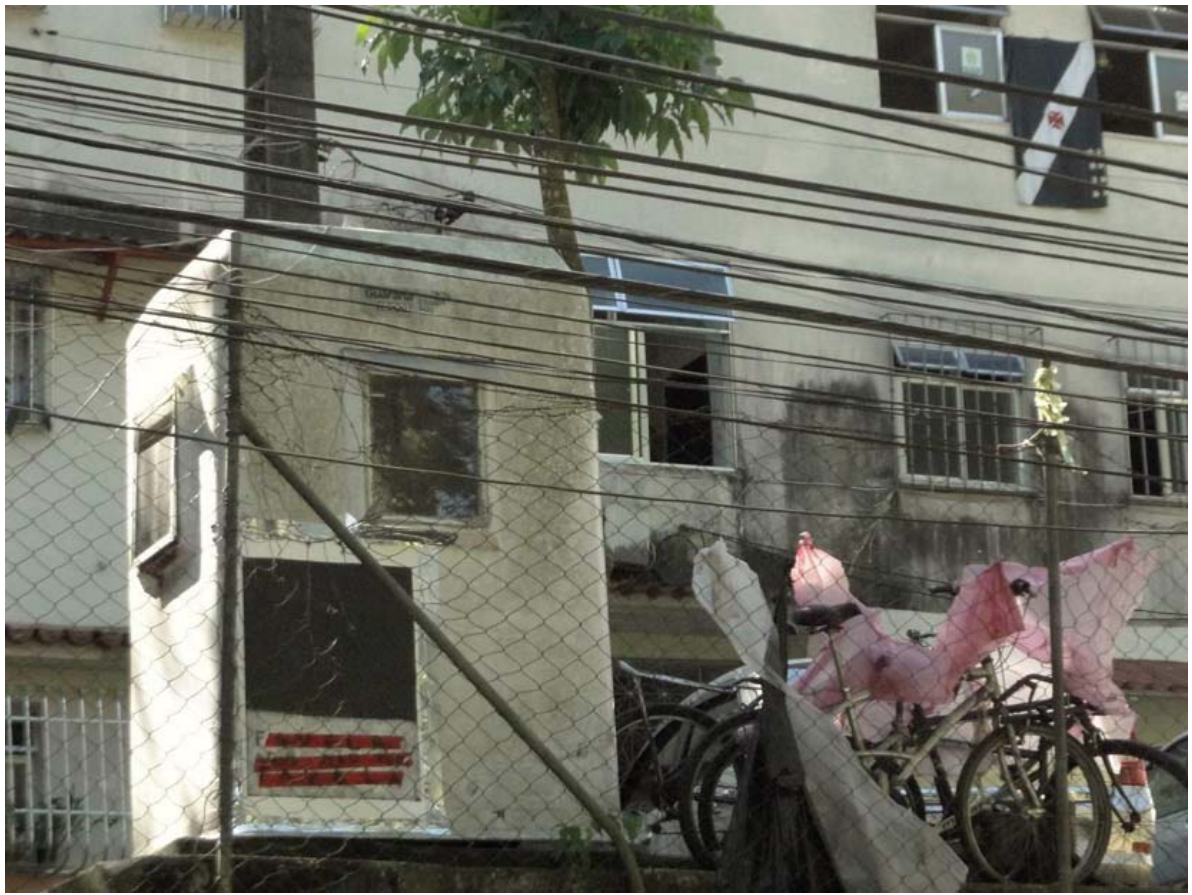

Marcelo Oliveira

Registro fotográfico das intervenções feitas nas comunidades próximas ao Parque Lage/Rio de Janeiro, a propósito da residência artística do PRÊMIO EAV PARQUE LAGE e MULTIPLO ESPAÇO ARTE 2014 


\section{heVistg all pautg}

\} NA PERIFERIA DO LUGAR - OLIVEIRA, M. \}

DOI: $10.12957 /$ REP.2016.25437

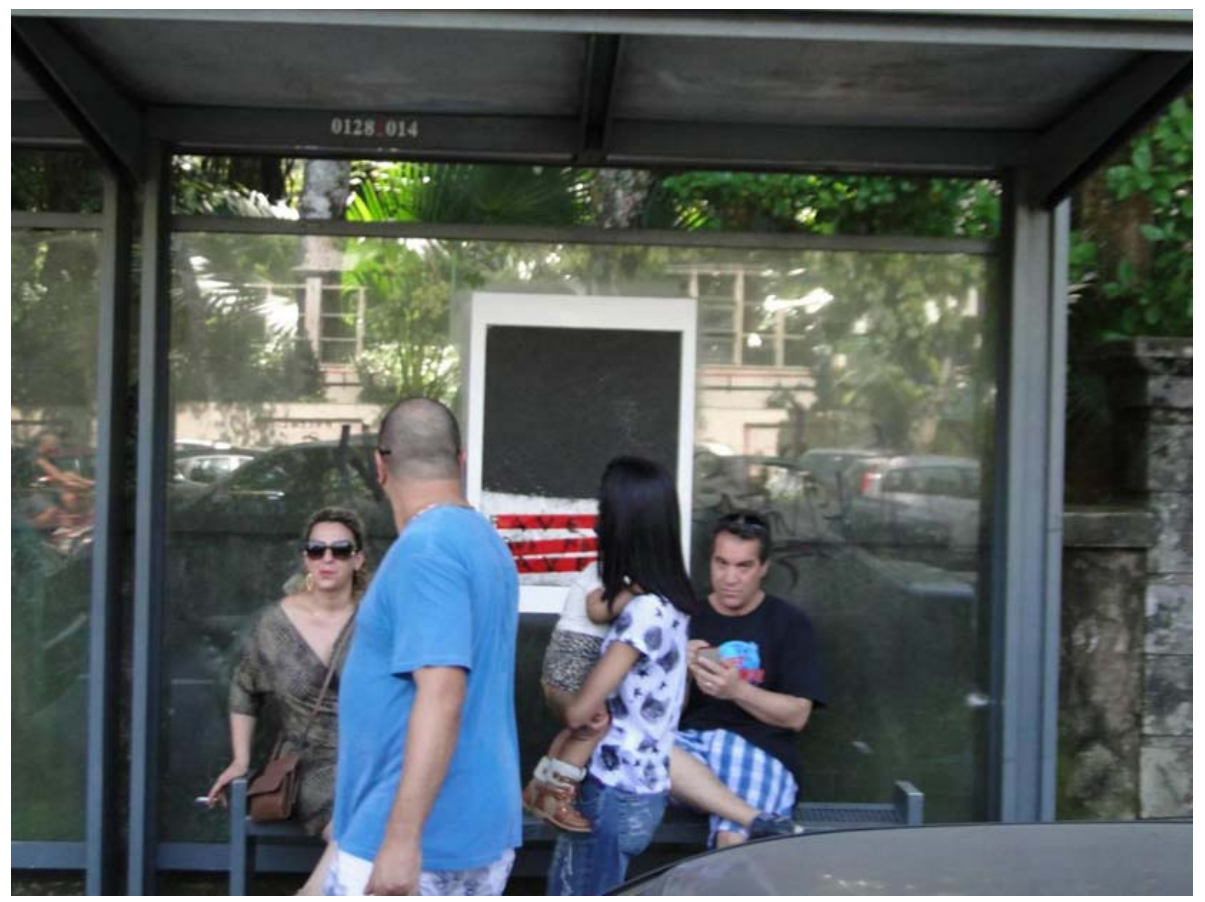

Marcelo Oliveira

Registro fotográfico das intervenções feitas nas comunidades próximas ao Parque Lage/Rio de Janeiro, a propósito da residência artística do PRÊMIO EAV PARQUE LAGE E MULTIPLO ESPAÇO ARTE 2014 


\section{ReVistg all pautg}

\} NA PERIFERIA DO LUGAR - OLIVEIRA, M. \}

DOI: $10.12957 / R E P .2016 .25437$

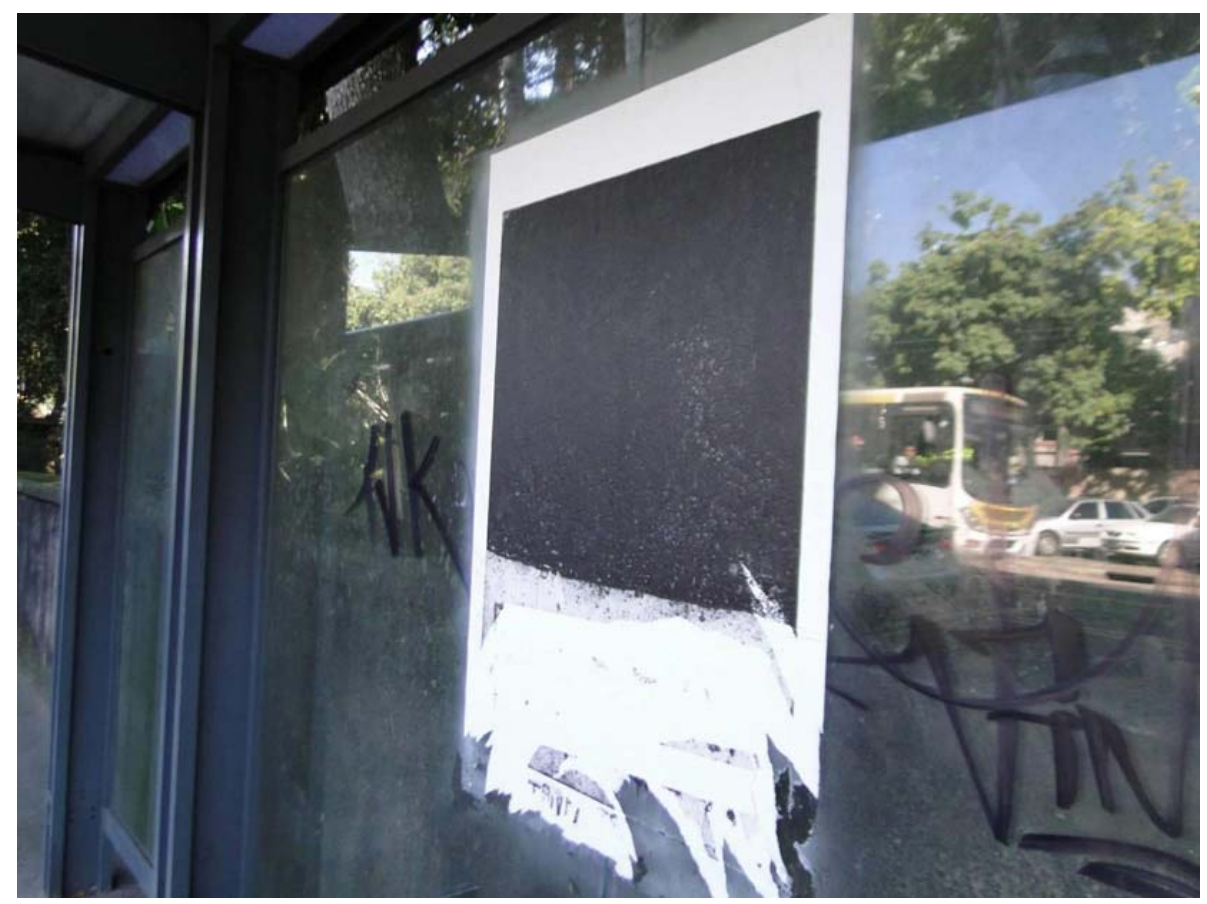

Marcelo Oliveira

Registro fotográfico das intervenções feitas nas comunidades próximas ao Parque Lage/Rio de Janeiro, a propósito da residência artística do PRÊMIO EAV PARQUE LAGE e MULTIPLO ESPAÇO ARTE 2014 


\section{heVistg all pautg}

\} NA PERIFERIA DO LUGAR - OLIVEIRA, M. \}

DOI: $10.12957 /$ REP.2016.25437

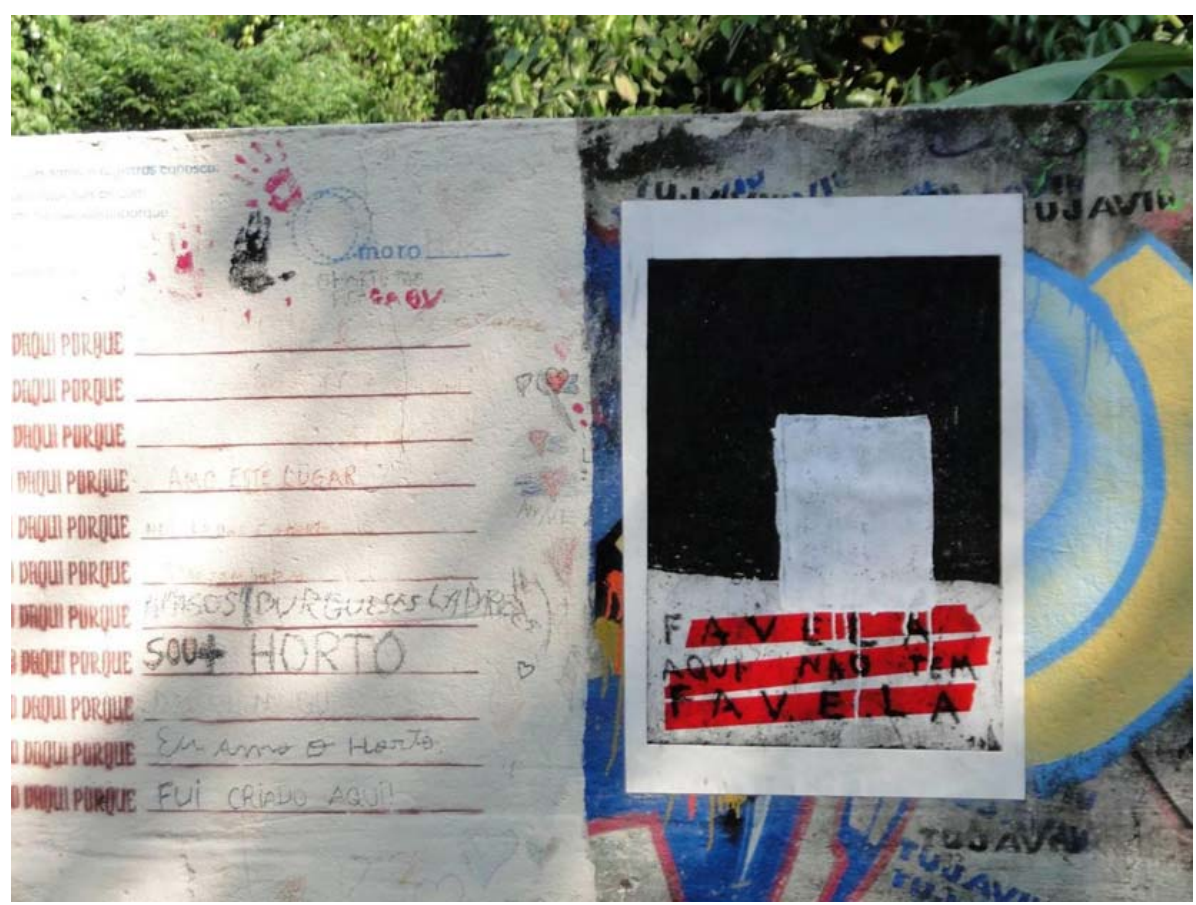

\section{Marcelo Oliveira}

Registro fotográfico das intervenções feitas nas comunidades próximas ao Parque Lage/Rio de Janeiro, a propósito da residência artística do PRÊMIO EAV PARQUE

LAGE e MULTIPLO ESPAÇO ARTE 2014 


\section{peVistg all paltg}

\} NA PERIFERIA DO LUGAR - OLIVEIRA, M. \}

DOI: $10.12957 / R E P .2016 .25437$

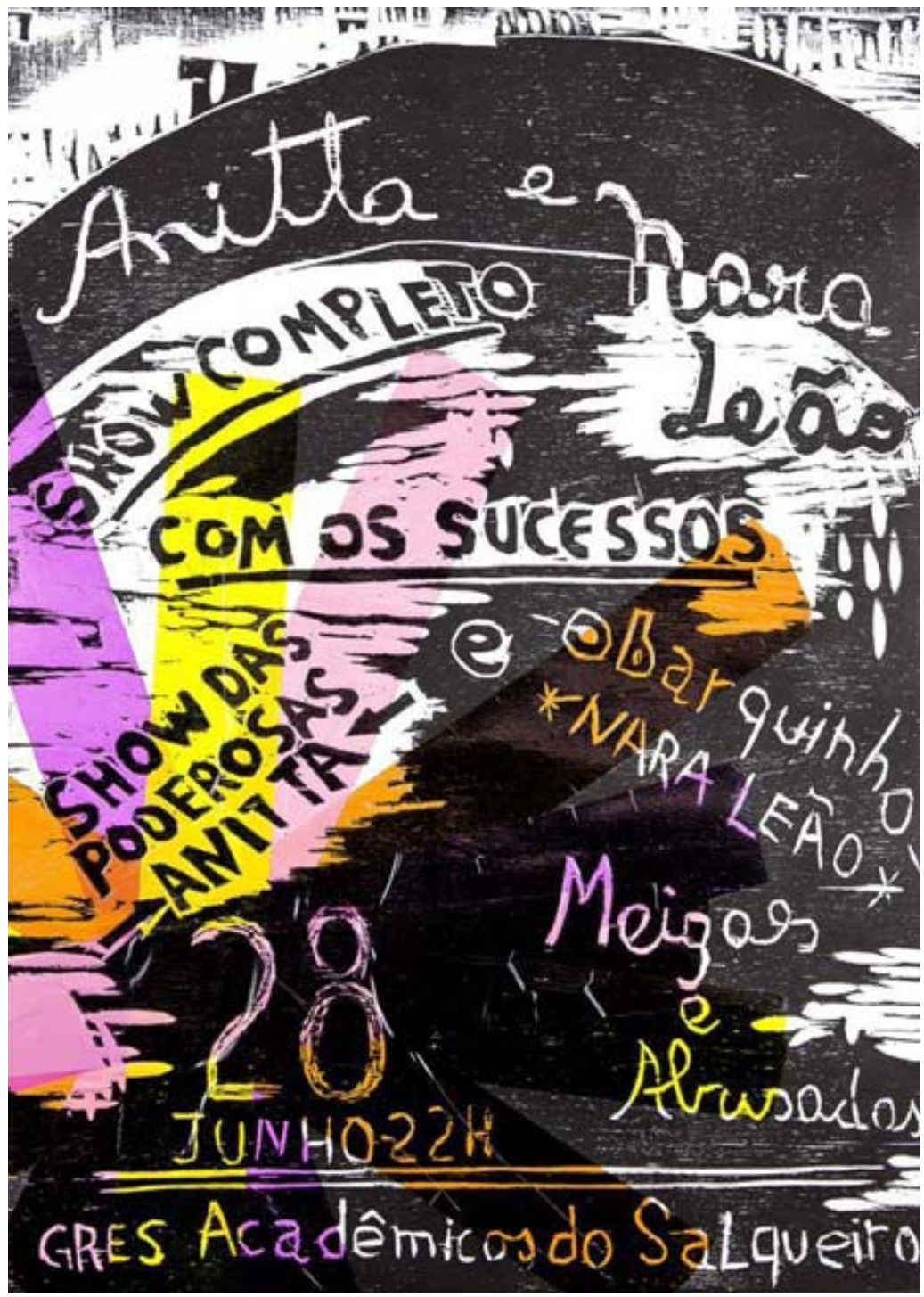

Marcelo Oliveira

Anitta e Nara Leão

2013

$50 \times 35$

Xilogravura e fita colorida adesivada s/papel rives 320g/m2 


\section{ReVistg all pautg}

\} NA PERIFERIA DO LUGAR - OLIVEIRA, M. \}

DOI: 10.12957/REP.2016.25437

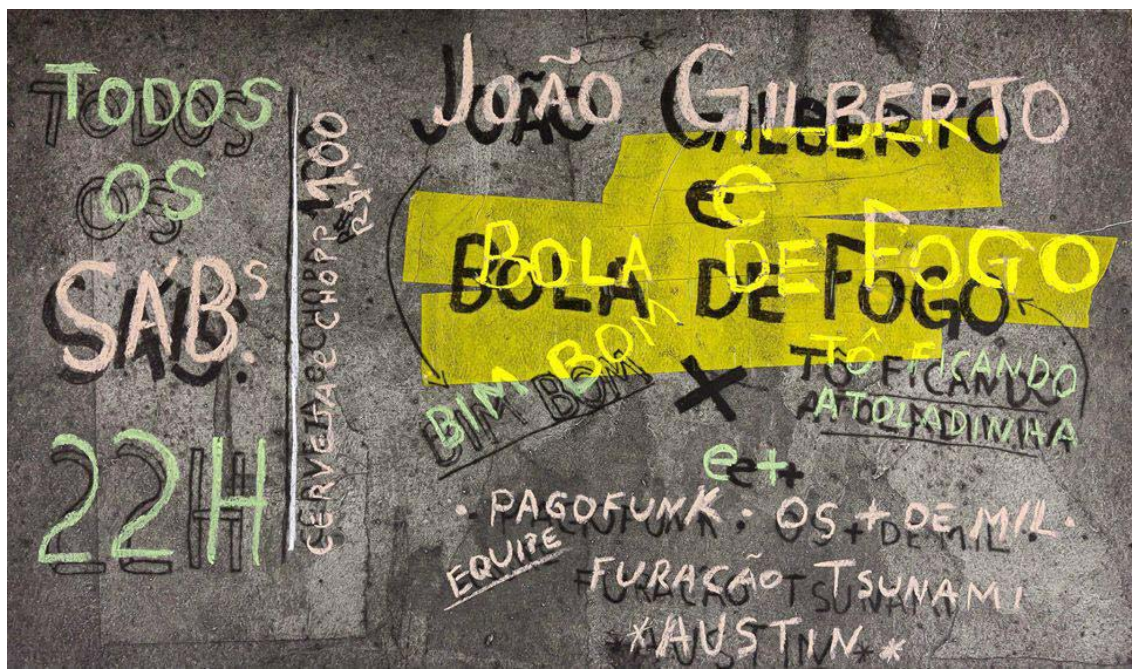

Marcelo Oliveira

João Gilberto e Bola de Fogo

2013

$35 \times 59$

gravura em côncavo, ponta seca, fita colorida adesivada e pastel seco, matrizes papel paraná e pvc, s/ papel rives $320 \mathrm{~g} / \mathrm{m} 2$ 


\section{ReVistg ell pautg}

\} NA PERIFERIA DO LUGAR - OLIVEIRA, M. \}

DOI: 10.12957/REP.2016.25437

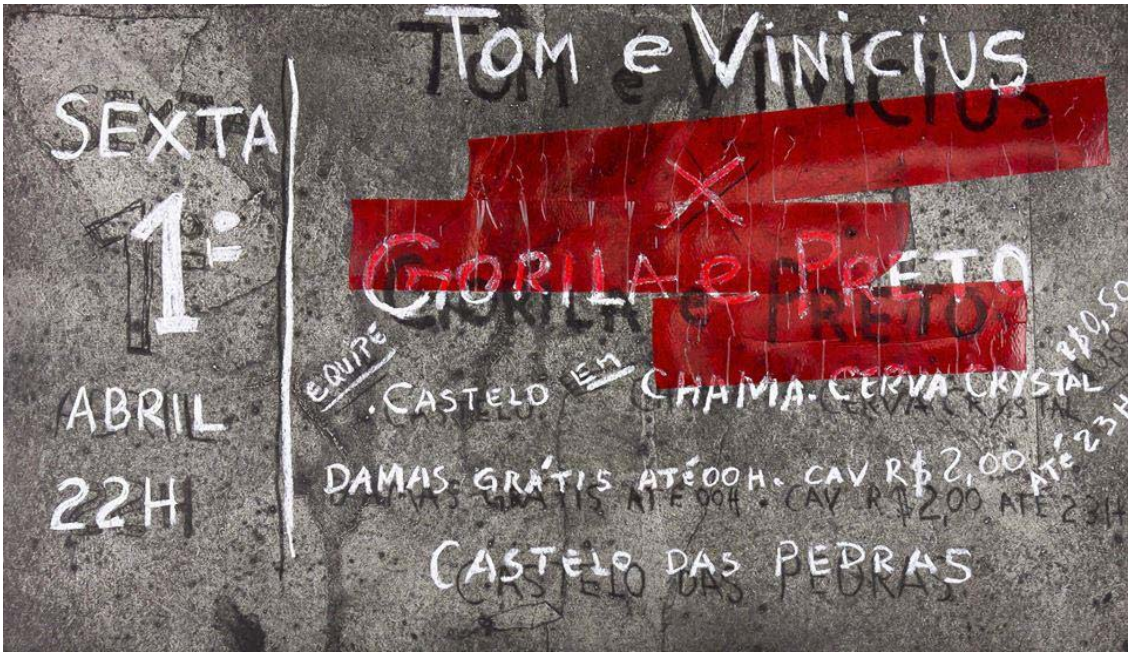

Marcelo Oliveira

Tom e Vinícius X Gorila e Preto

2013

$35 \times 59$

Gravura em côncavo, ponta seca, fita colorida adesivada e pastel seco, matrizes papel paraná e pvc, s/ papel rives $320 \mathrm{~g} / \mathrm{m} 2$ 


\section{ReVistg all pautg}

[ NA PERIFERIA DO LUGAR - OLIVEIRA, M. \}

DOI: 10.12957/REP.2016.25437

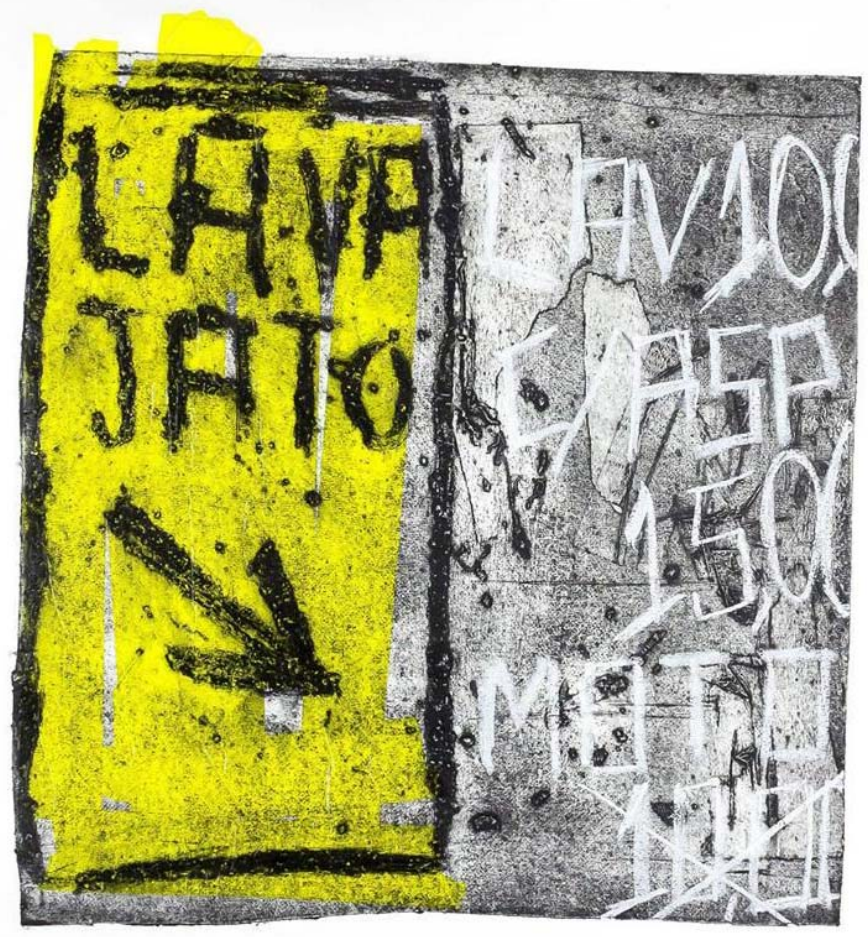

Marcelo Oliveira

Lava-Jato II

2012

$70 \times 68 \mathrm{~cm}$

gravura em côncavo, fita colorida adesivada e giz escolar, matriz papel paraná, s/ papel rives $320 \mathrm{~g} / \mathrm{m} 2$ 


\section{ReVistg ell pautg}

\} NA PERIFERIA DO LUGAR - OLIVEIRA, M. \}

DOI: $10.12957 /$ REP.2016.25437

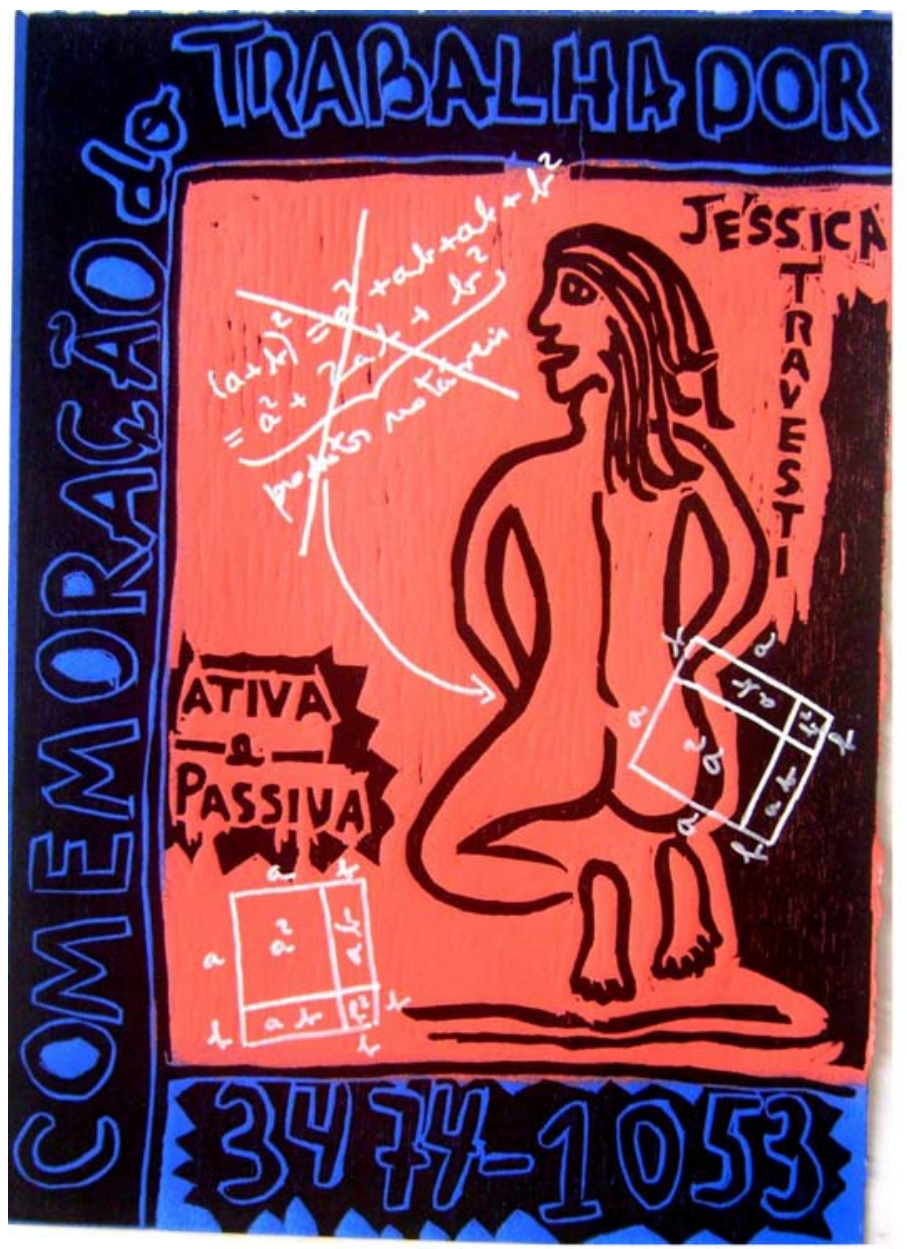

Marcelo Oliveira

PRAÇA XV

2014

$42,5 \times 30,5$

Xilogravura - tinta acrílica, guache e caneta permanente

EM PAUTA, Rio de Janeiro - $1{ }^{\circ}$ Semestre de 2016 - n. 37, v. 14, p. 319 - 351 


\section{ReVistg all pantg}

\} NA PERIFERIA DO LUGAR - OLIVEIRA, M. \}

DOI: 10.12957/REP.2016.25437

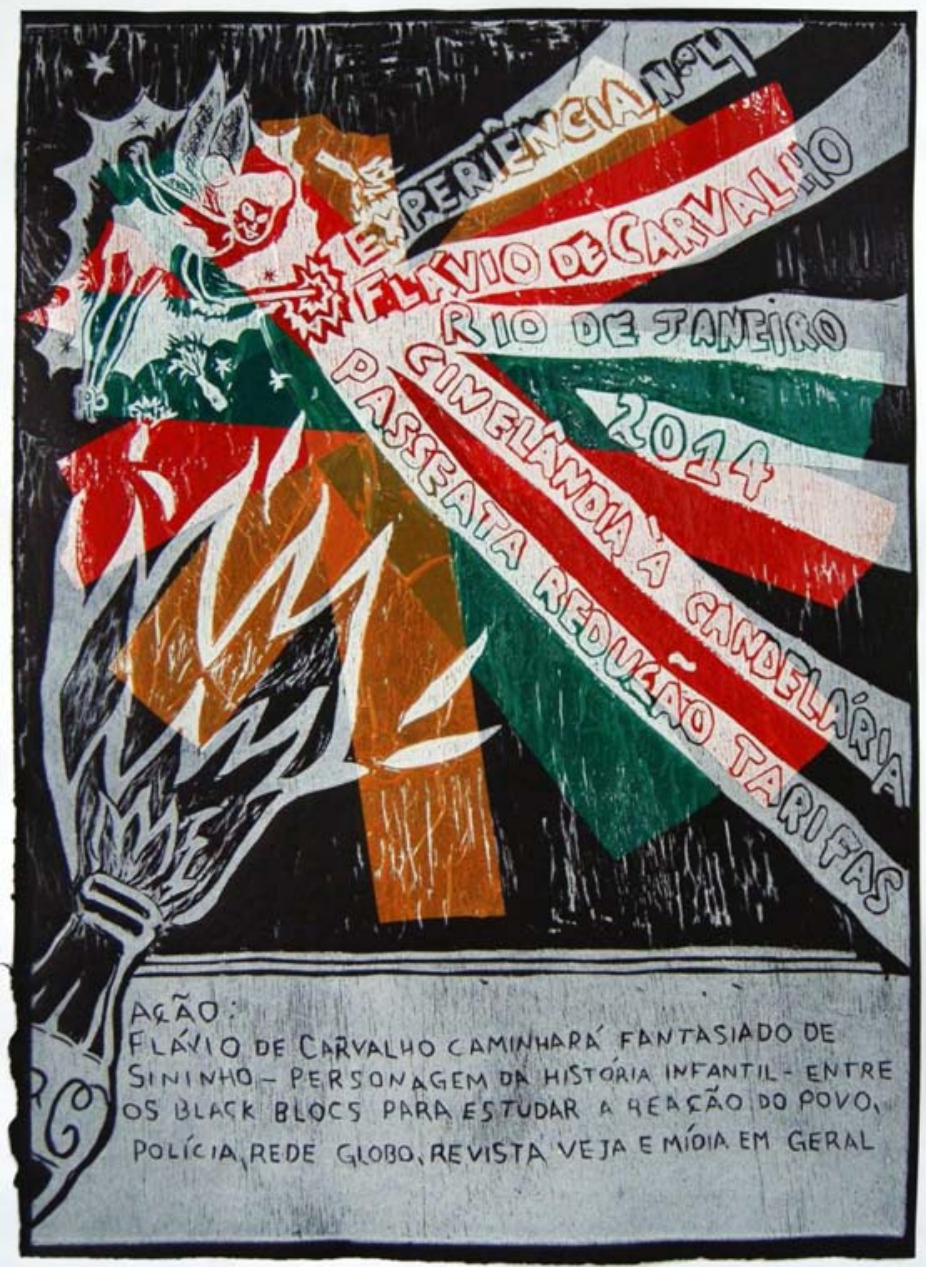

Marcelo Oliveira

Experiência no ${ }^{\circ}$ - Flávio de Carvalho

2014

$50 \times 35 \mathrm{~cm}$

Xilogravura e fita colorida adesivada, s/ papel rives preto $320 \mathrm{~m} / 2$ 


\section{ReVistg ell pautg}

\} NA PERIFERIA DO LUGAR - OLIVEIRA, M. \}

DOI: 10.12957/REP.2016.25437

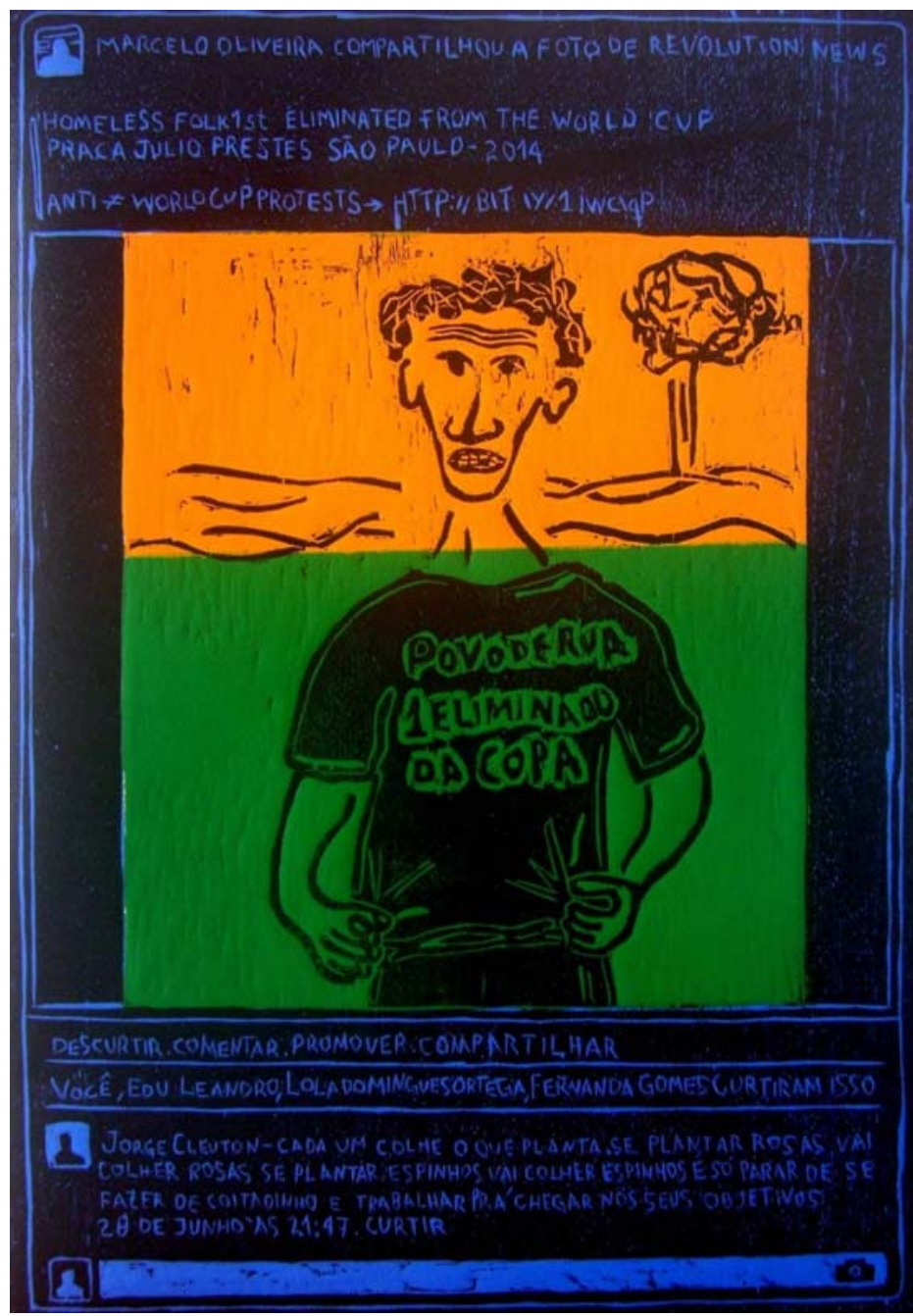

Marcelo Oliveira

COMENTÁRIO NO FACE BOOK

2014

$50 \times 35 \mathrm{~cm}$

Xilogravura, tinta acrílica e guache

EM PAUTA, Rio de Janeiro - 1 $^{\circ}$ Semestre de 2016 - n. 37, v. 14, p. 319 - 351 


\section{ReVistg all pautg}

\} NA PERIFERIA DO LUGAR - OLIVEIRA, M.

DOI: 10.12957/REP.2016.25437

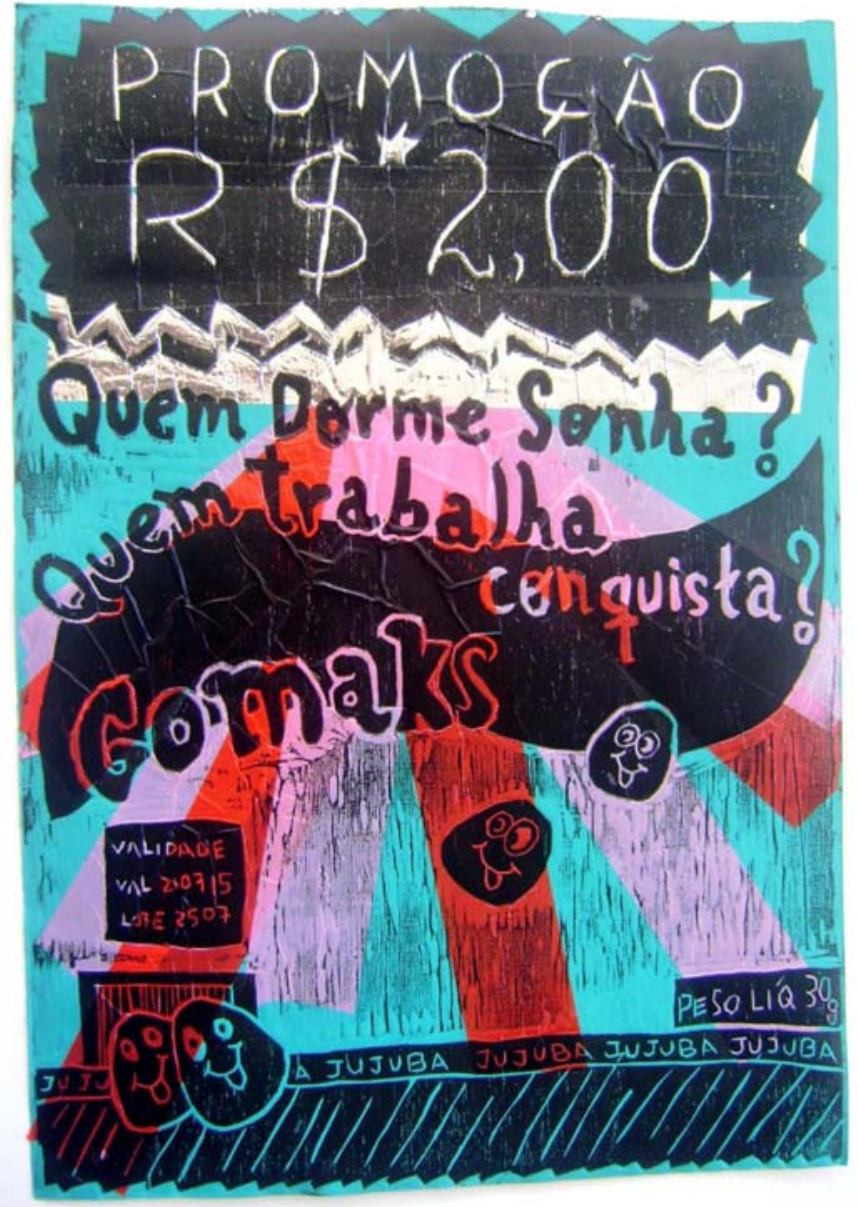

Marcelo Oliveira

QUEM DORME SONHA? II

2015

$50 \times 35 \mathrm{~cm}$

Xilogravura, tinta acrílica e fitas adesivas coloridas, s/papel rives 320g/m2 


\section{ReVistg ell pautg}

\} NA PERIFERIA DO LUGAR - OLIVEIRA, M. \}

DOI: 10.12957/REP.2016.25437

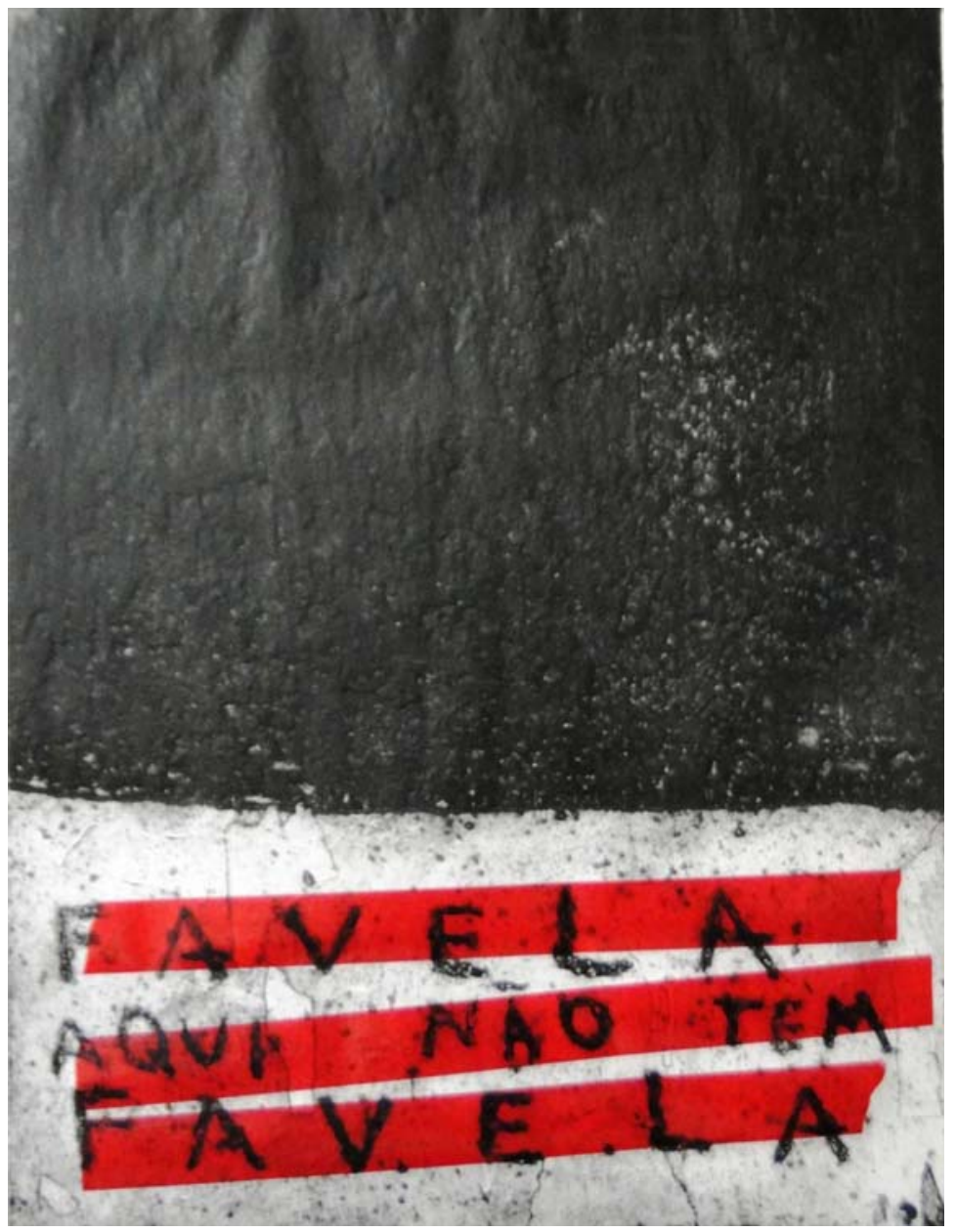

Marcelo Oliveira

Tem alguma comunidade por aqui?

2014

$100 \times 70 \mathrm{~cm}$

Gravura em côncavo e fita adesiva colorida, matriz papel Paraná, s/ papel rives $320 \mathrm{~g} / \mathrm{m} 2$ 


\section{heVistg all pautg}

\} NA PERIFERIA DO LUGAR - OLIVEIRA, M. \}

DOI: $10.12957 /$ REP.2016.25437

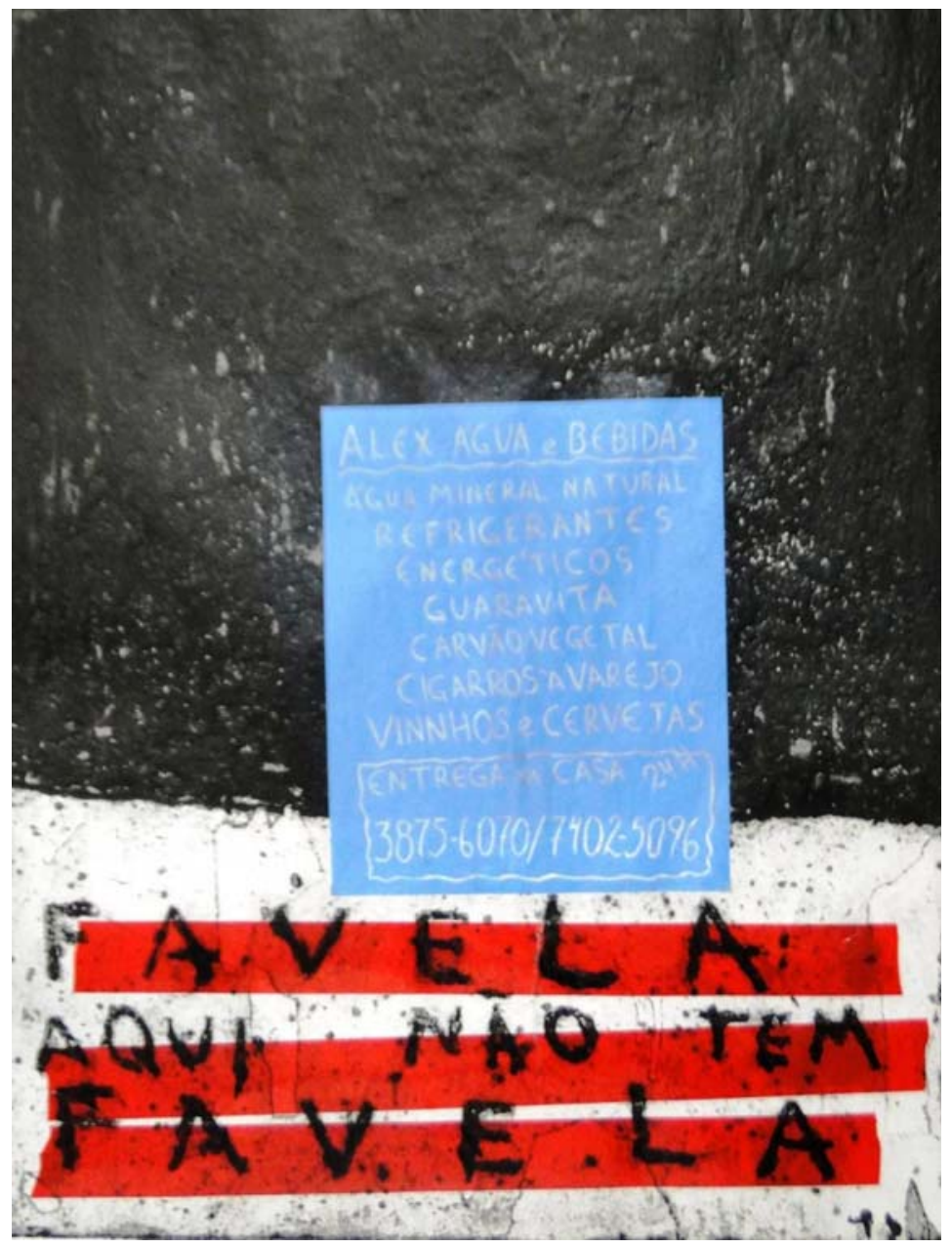

Marcelo Oliveira

Delivery

2014

$100 \times 70 \mathrm{~cm}$

Gravura em côncavo e fita adesiva colorida, matriz papel Paraná, s/ papel rives $320 \mathrm{~g} / \mathrm{m} 2$ e xilogravura, matriz de PVC s/papel de arroz 


\section{ReVistg ell pautg}

\} NA PERIFERIA DO LUGAR - OLIVEIRA, M. \}

DOI: 10.12957/REP.2016.25437

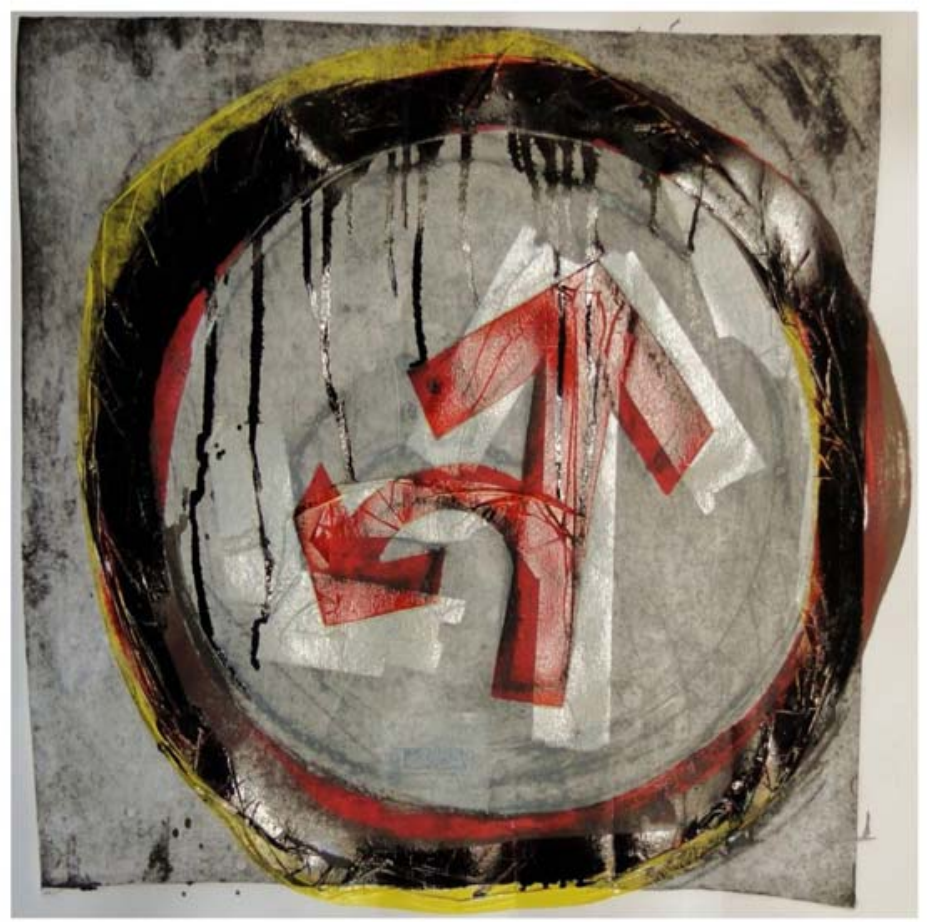

Marcelo Oliveira

Desvio na Mendes Sá

2012

$70 \times 65 \mathrm{~cm}$

Gravura em côncavo, intervenção com fita colorida, tinta asfáltica e stencil

EM PAUTA, Rio de Janeiro - 1 $^{\circ}$ Semestre de 2016 - n. 37, v. 14, p. 319 - 351 


\section{heVistg all pautg}

\} NA PERIFERIA DO LUGAR - OLIVEIRA, M. \}

DOI: 10.12957/REP.2016.25437

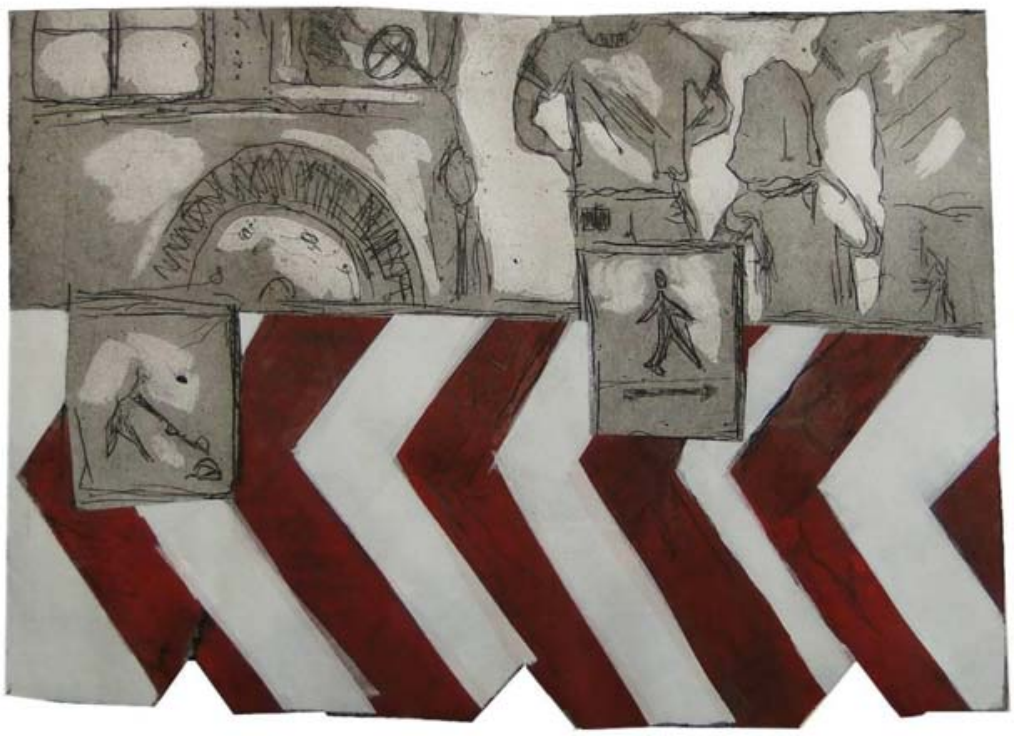

\section{Marcelo Oliveira}

Na rua, na pista...

2012

$65 \times 40 \mathrm{~cm}$

Gravura em côncavo, matriz de pvc, s/ papel rives 320m2 


\section{ReVistg all pautg}

\} NA PERIFERIA DO LUGAR - OLIVEIRA, M. \}

DOI: $10.12957 /$ REP.2016.25437

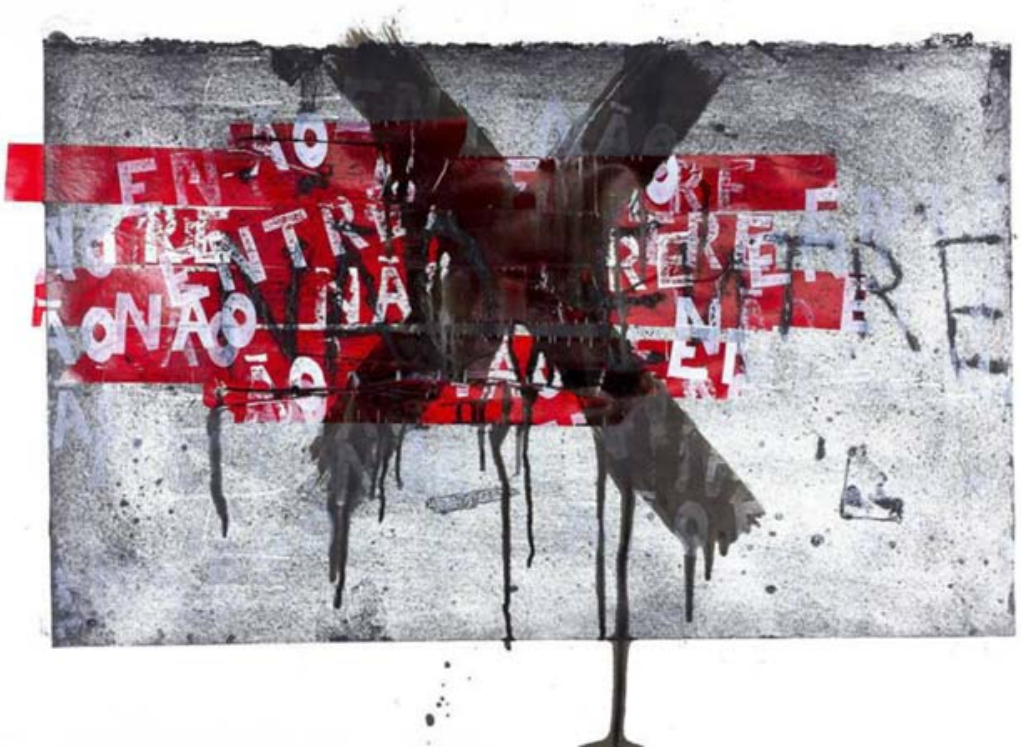

Marcelo Oliveira

NÃO ENTRE!!!

2012

$70 \times 100 \mathrm{~cm}$

Gravura em côncavo, ponta seca, fita adesiva e carimbo, matriz papel paraná, s/ papel rives $320 \mathrm{~g} / \mathrm{m} 2$ 


\section{heVistg all pautg}

\} NA PERIFERIA DO LUGAR - OLIVEIRA, M. \}

DOI: $10.12957 /$ REP.2016.25437

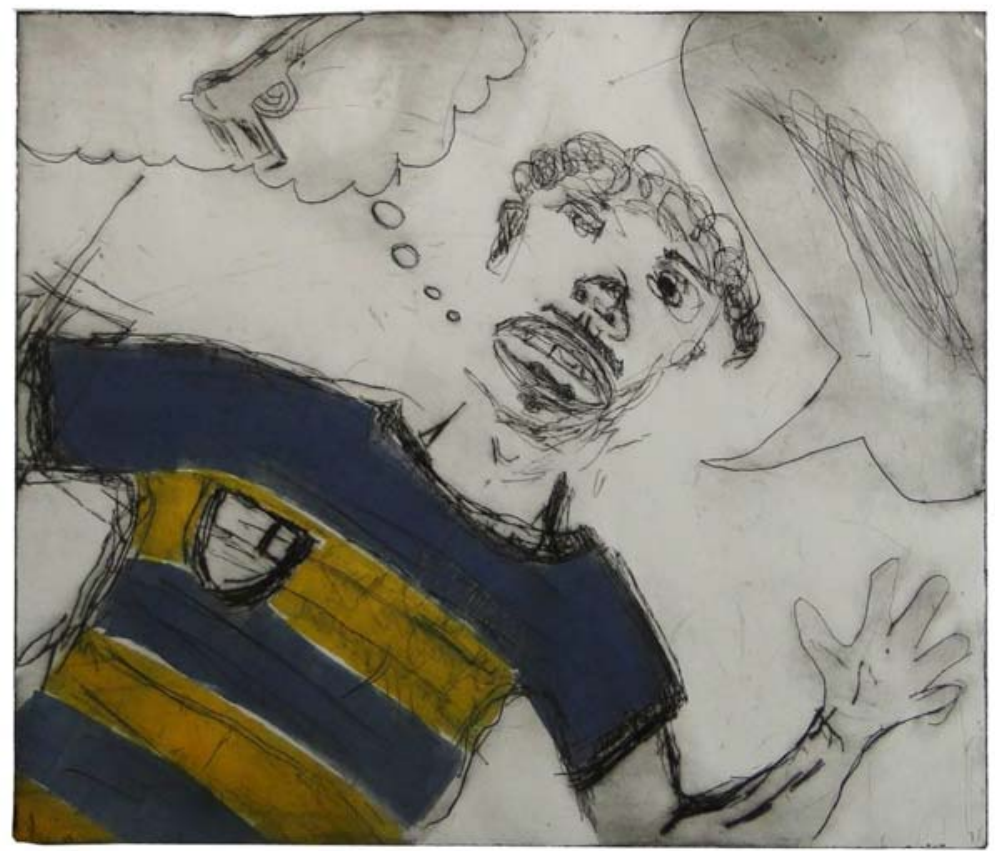

\section{Marcelo Oliveira}

Perdeu Playboy!!

2011

$60 \times 50 \mathrm{~cm}$

Gravura em côncavo, ponta seca, matriz pvc, s/ papel rives 320g/m2 


\section{ReVistg ell pautg}

\} NA PERIFERIA DO LUGAR - OLIVEIRA, M. \}

DOI: 10.12957/REP.2016.25437

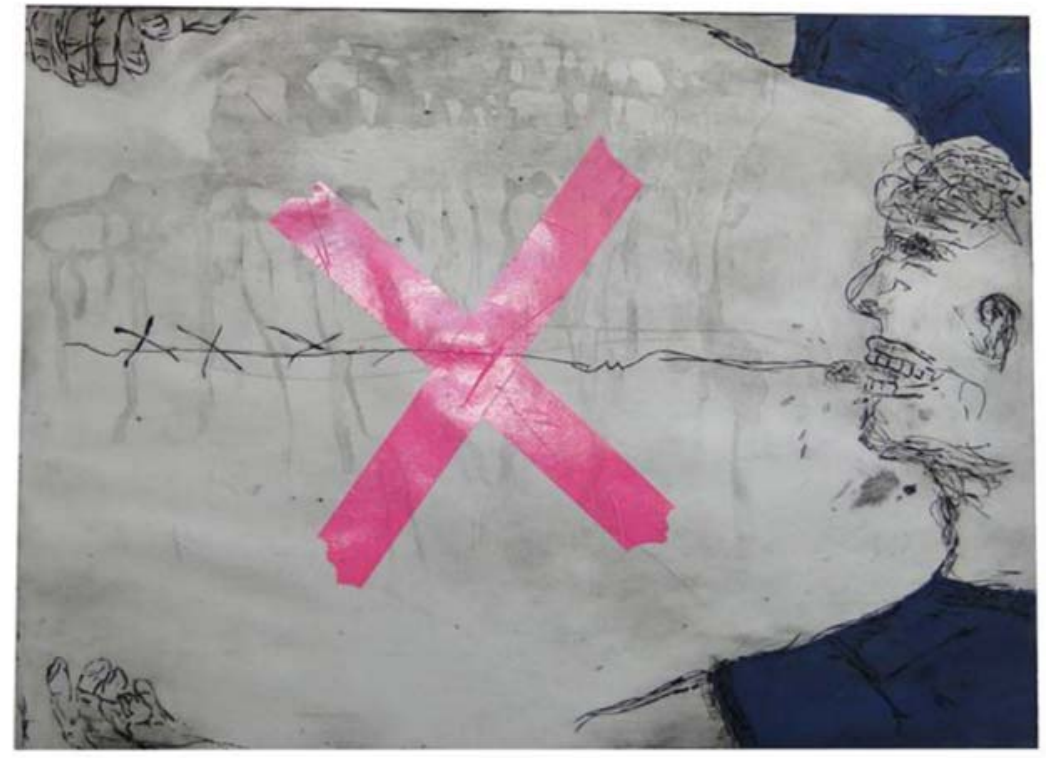

Marcelo Oliveira

PAPO RETO!

2012

$100 \times 70 \mathrm{~cm}$

Gravura em côncavo, ponta seca e fita adesiva colorida, matriz PVC, s/ papel rives 320g/ $\mathrm{m} 2$ 


\section{ReVistg all pautg}

\} NA PERIFERIA DO LUGAR - OLIVEIRA, M.

DOI: 10.12957/REP.2016.25437

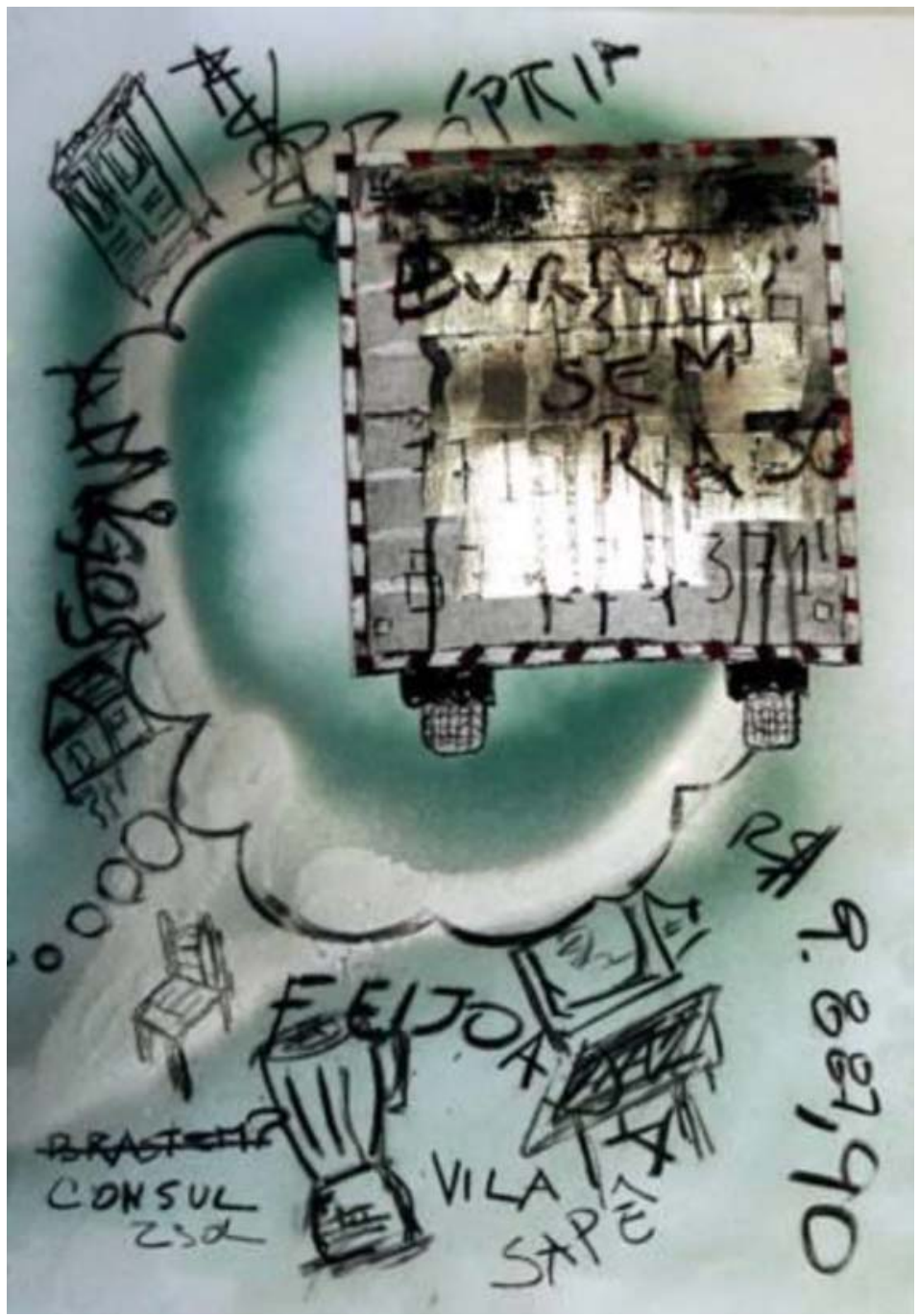

Marcelo Oliveira

MUDANÇA I

Gravura ęm côncavo, spray e carvão e fita adesiva metalizada $70 \times 50-2012$ 


\section{ReVistg eml paUtg}

\} NA PERIFERIA DO LUGAR - OLIVEIRA, M. \}

DOI: 10.12957/REP.2016.25437

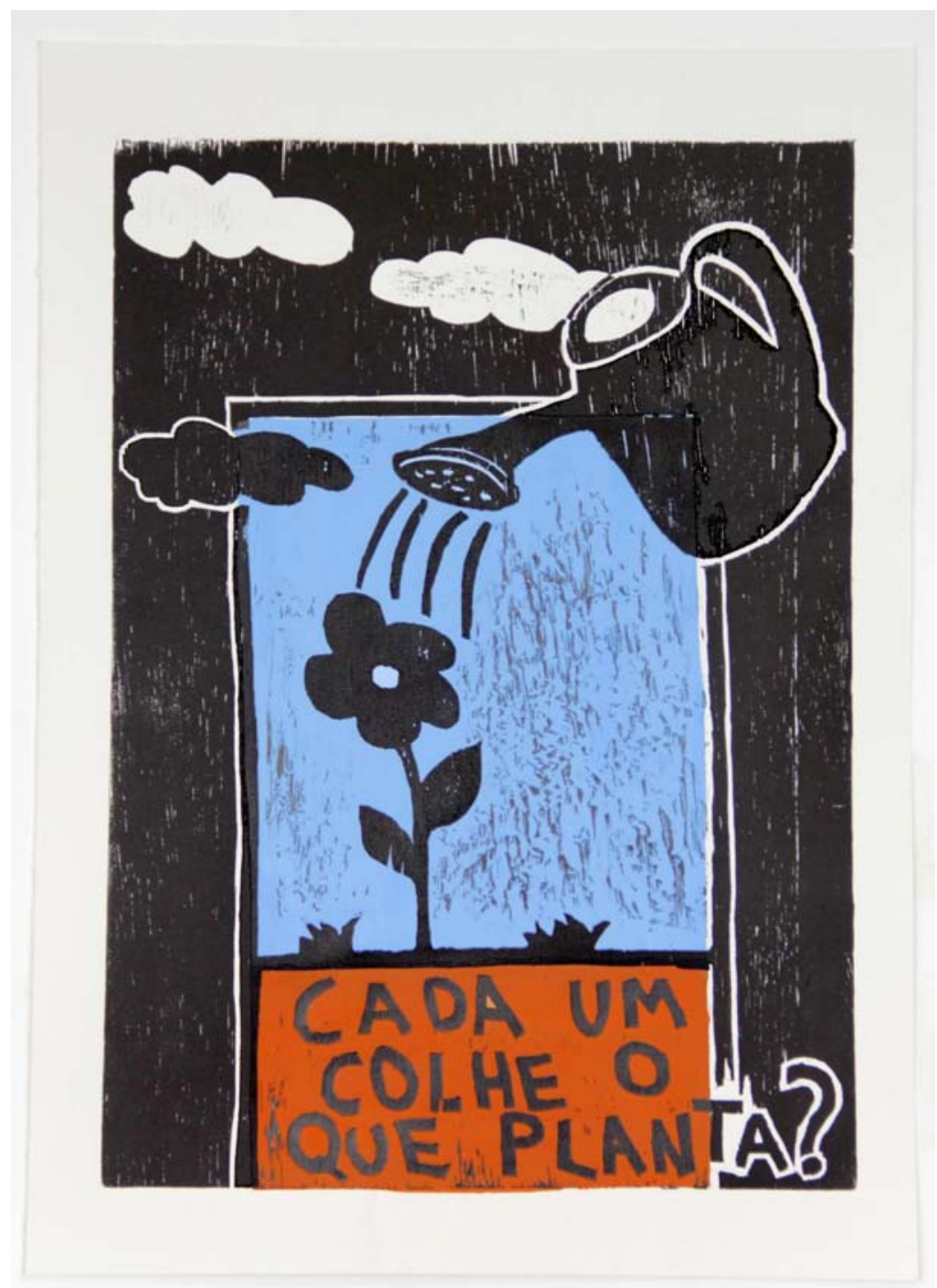

Marcelo Oliveira

CADA UM COLHE O QUE PLANTA

xilogravura e tinta guache s papel rives $70 \times 50 \mathrm{~cm} 270 \mathrm{gm} 2$

2015

EM PAUTA, Rio de Janeiro - ${ }^{\circ}$ Semestre de 2016 - n. 37, v. 14, p. 319 - 351 


\section{heVistg all pautg}

\} NA PERIFERIA DO LUGAR - OLIVEIRA, M. \}

DOI: 10.12957/REP.2016.25437

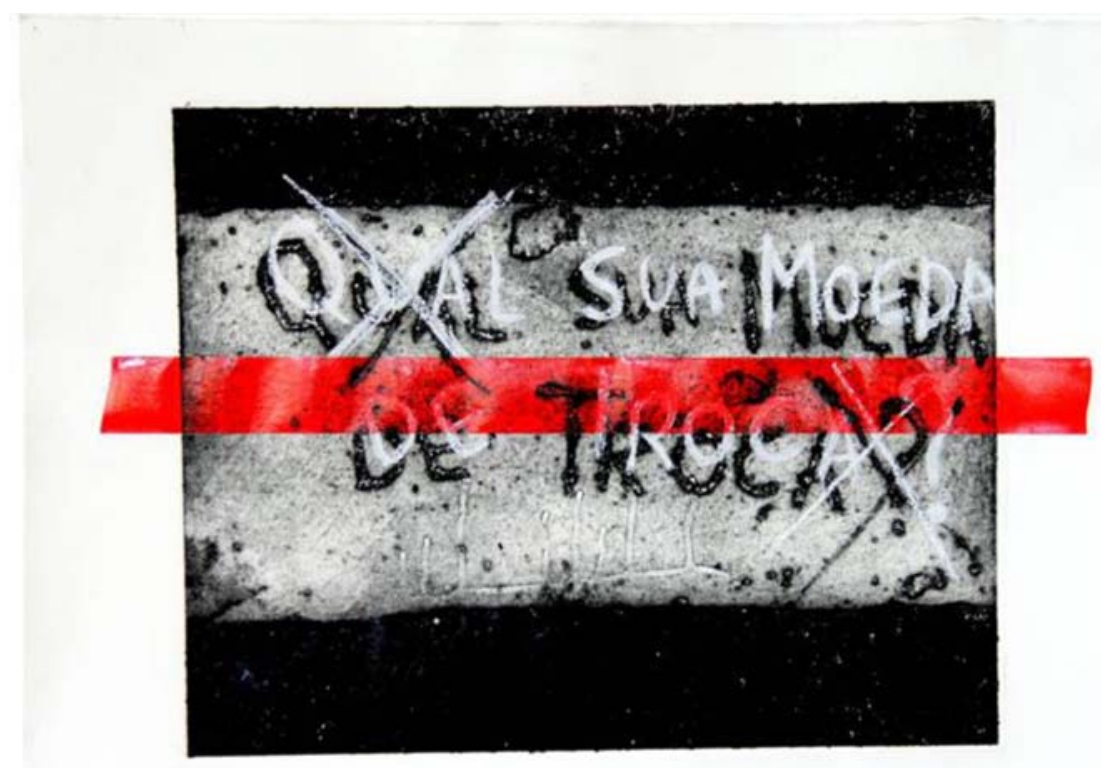

Marcelo Oliveira

SUA MOEDA DE TROCA

grauvura em côncavo, fita adesiva colorida

$50 \times 70 \mathrm{~cm}$

2015 


\section{ReVistg all pautg}

\} NA PERIFERIA DO LUGAR - OLIVEIRA, M. \}

DOI: $10.12957 /$ REP.2016.25437
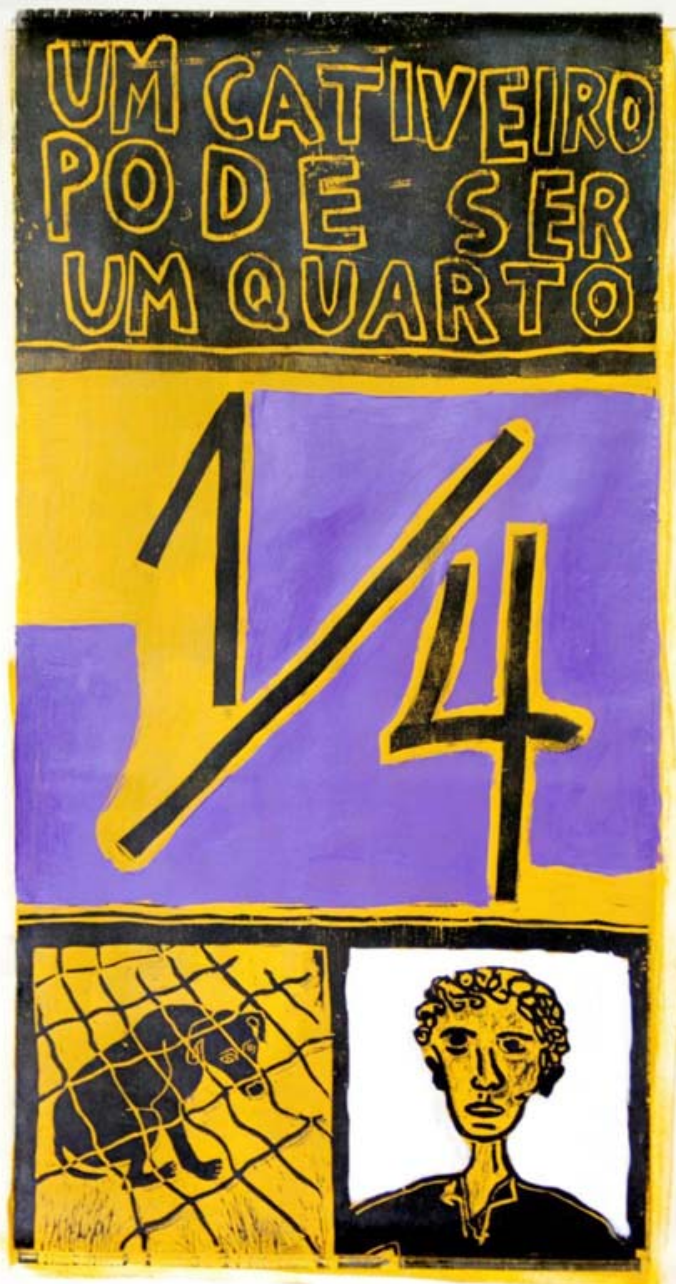

Marcelo Oliveira

UM CATIVEIRO PODE SER UM QUARTO

xilogravura e tinta acrílica

$100 \times 70 \mathrm{~cm}$

2016

EM PAUTA, Rio de Janeiro - ${ }^{\circ}$ Semestre de 2016 - n. 37, v. 14, p. 319 - 351 


\title{
heVistg all pautg
}

[ NA PERIFERIA DO LUGAR - OLIVEIRA, M. \}

DOI: 10.12957/REP.2016.25437

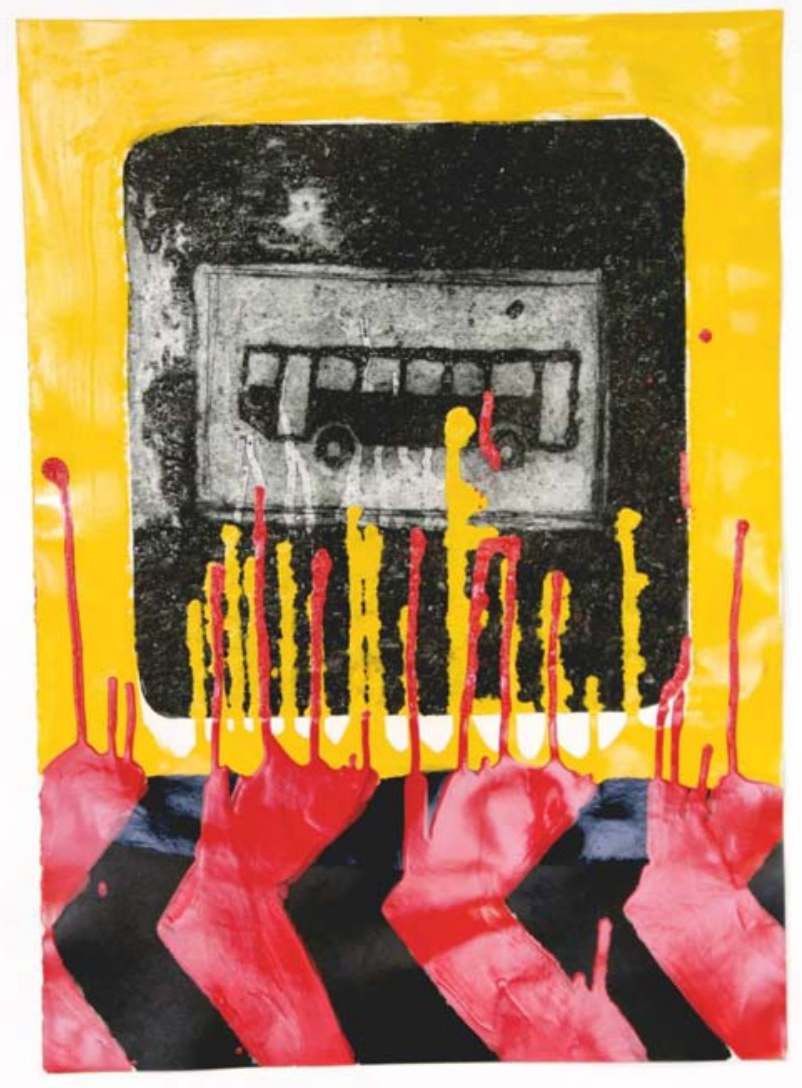

\begin{abstract}
Marcelo Oliveira
UMA INFINIDADE DE PONTOS FORMAM UMA LINHA gravura em côncavo e tinta esmalte - s papel rives $270 \mathrm{gm}^{2}$ $70 \times 50$

2015
\end{abstract}




\section{ReVistg ell pautg}

\} NA PERIFERIA DO LUGAR - OLIVEIRA, M. \}

DOI: 10.12957/REP.2016.25437

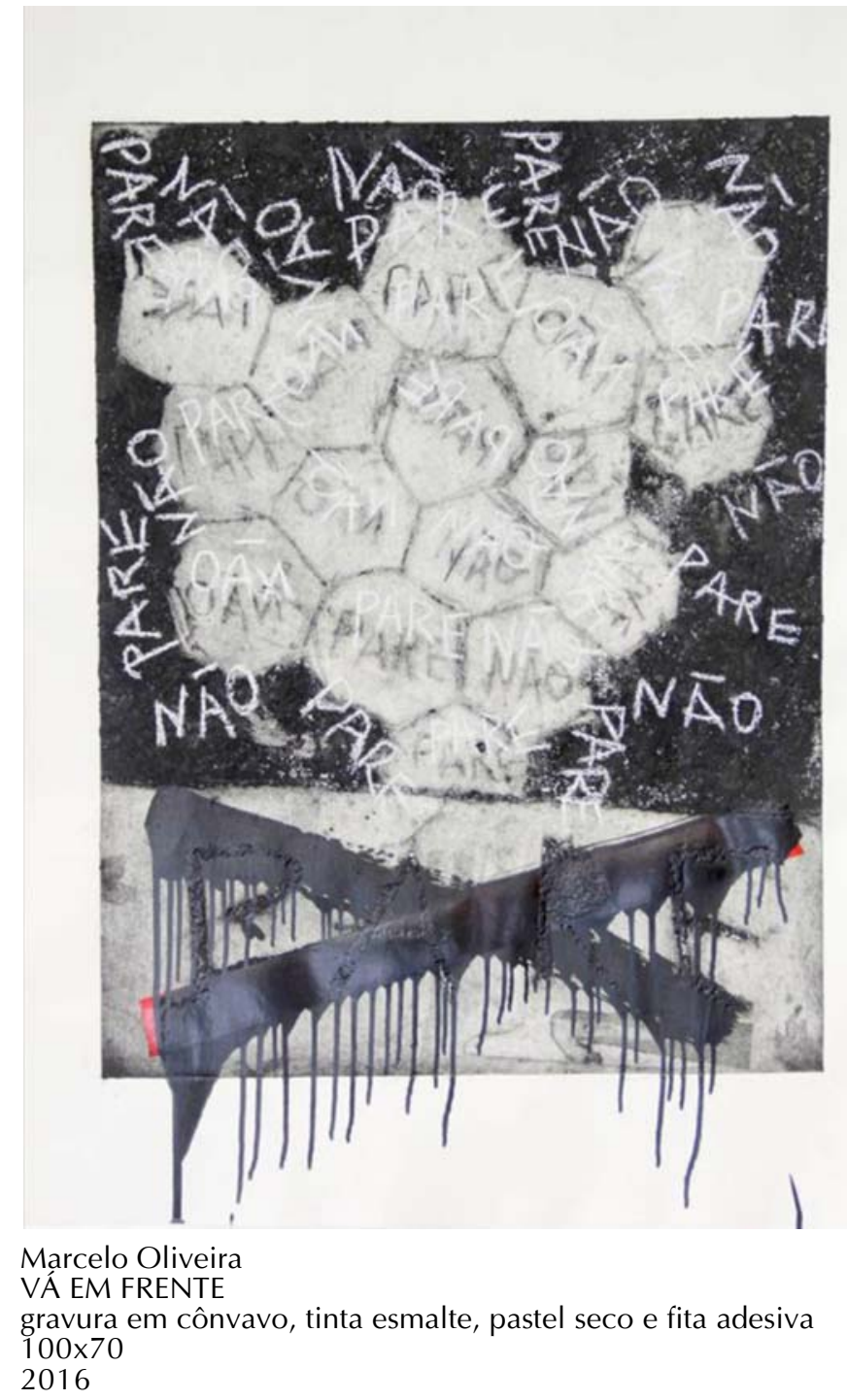

EM PAUTA, Rio de Janeiro - ${ }^{\circ}$ Semestre de 2016 - n. 37, v. 14, p. 319 - 351 


\section{heVistg all pautg}

[ NA PERIFERIA DO LUGAR - OLIVEIRA, M. \}

DOI: $10.12957 /$ REP.2016.25437

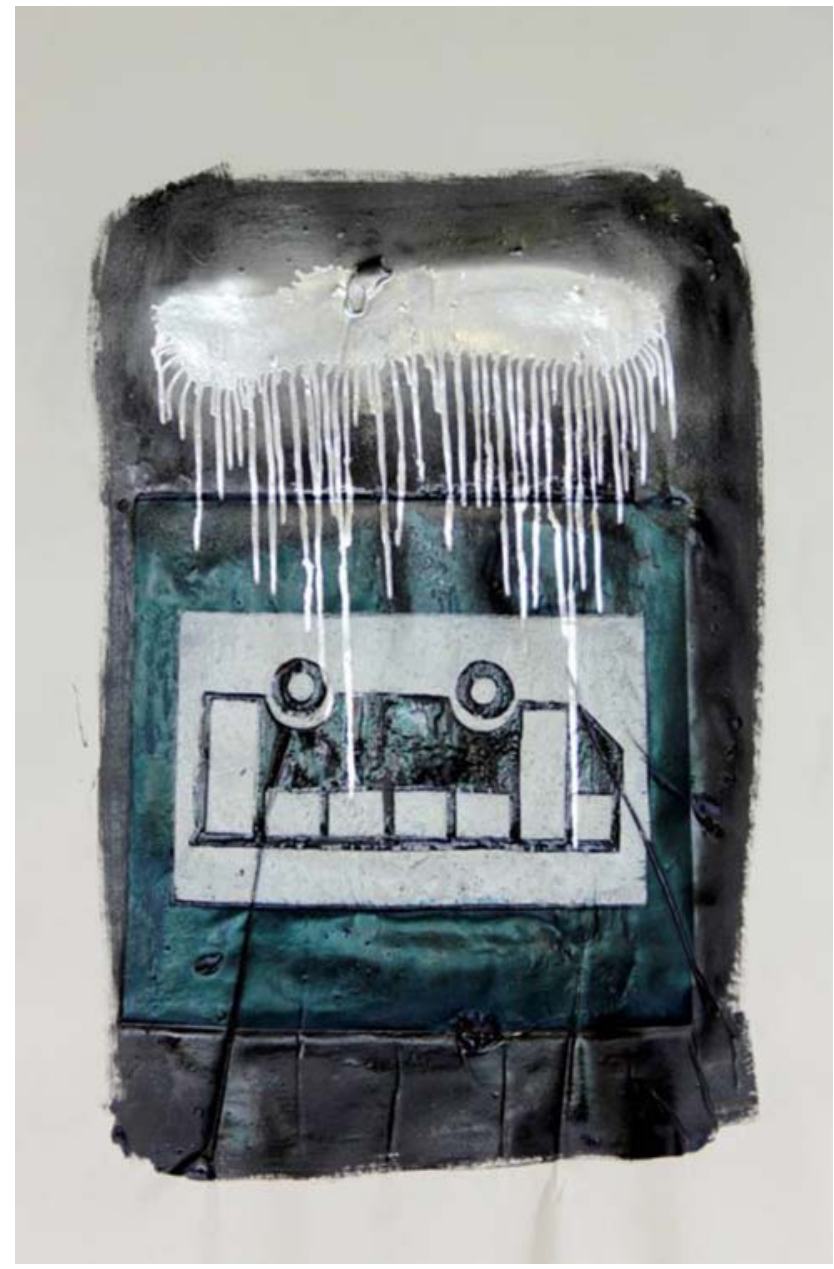

\section{Marcelo Oliveira}

UMA INFINIDADE DE PONTOS FORMA UMA LINHA 2

gravura em côncavo, tinta industrial e spray s papel rives $270 \mathrm{gm} 2$

$100 \times 70$

2015 


\section{ReVistg ell pautg}

\} NA PERIFERIA DO LUGAR - OLIVEIRA, M. \}

DOI: 10.12957/REP.2016.25437

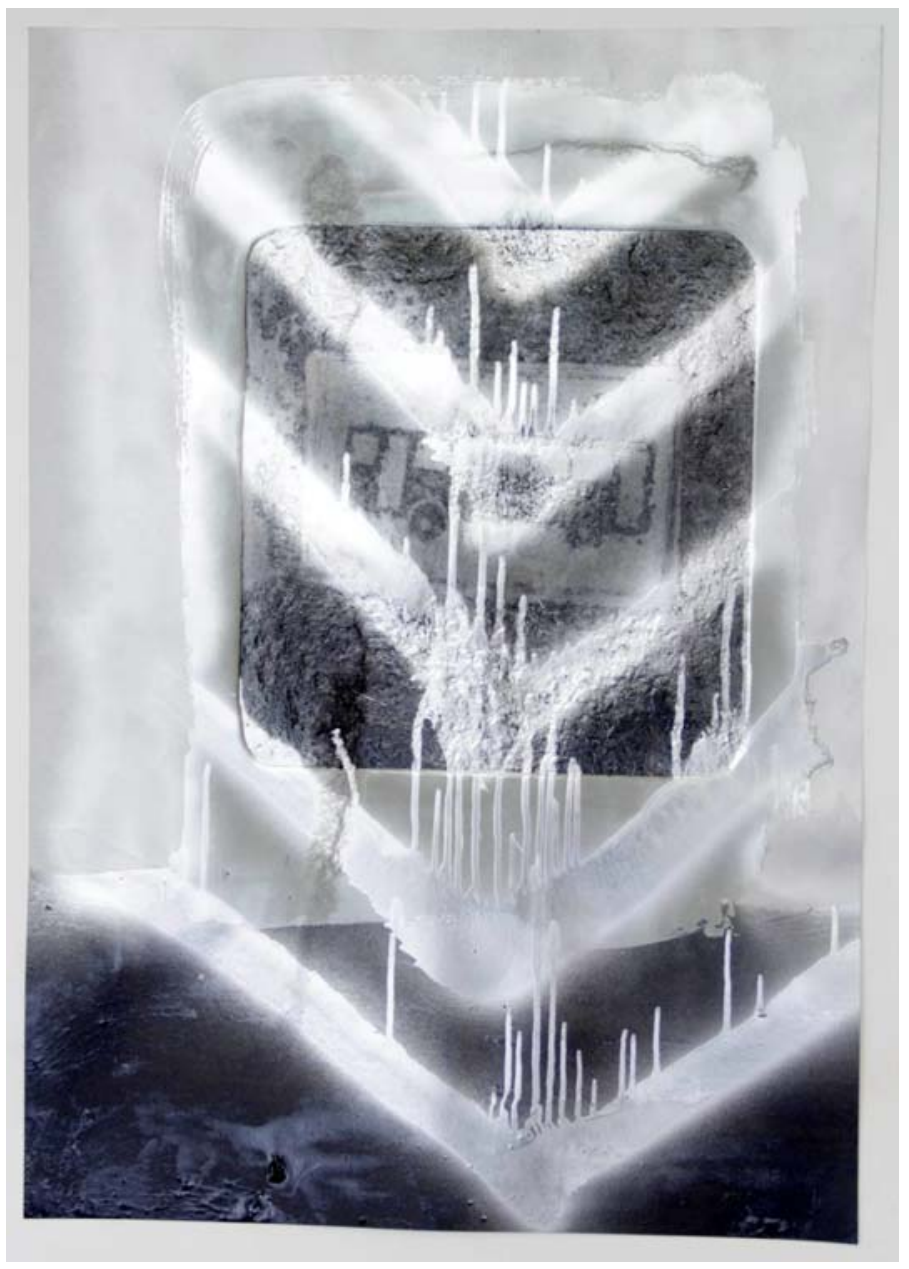

\section{Marcelo Oliveira \\ NÃO SE CONFIA EM SETAS \\ gravura em côncavo, tinta industrial e spray \\ $90 \times 65$ \\ 2016}

EM PAUTA, Rio de Janeiro - 1 $^{\circ}$ Semestre de 2016 - n. 37, v. 14, p. 319 - 351 


\section{ReVista all pautg}

\} NA PERIFERIA DO LUGAR - OLIVEIRA, M. \}

DOI: 10.12957/REP.2016.25437

DOI: 10.12957/rep.2016.25437

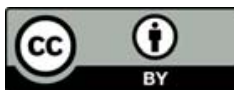

A Revista Em Pauta: Teoria Social e Realidade Contemporânea está licenciada com uma Licença Creative Commons Atribuição 4.0 Internacional.

EM PAUTA, Rio de Janeiro - $1^{\circ}$ Semestre de 2016 - n. 37, v. 14, p. 319 - 351

Revista da Faculdade de Serviço Social da Universidade do Estado do Rio de Janeiro 